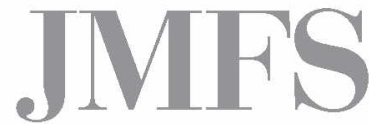

Journal of Management and Financial Sciences
Volume X

-

Issue 28 (June 2017)

pp. 37-71

Warsaw School of Economics

Collegium of Management and Finance

\title{
Aleksandra Wąsowska
}

Faculty of Management

University of Warsaw

\section{Venturing to Distant Markets \\ - Polish Firms in Latin America}

\section{ABSTRACT}

The objective of this paper is to shed light on the understudied phenomenon of expansion of Polish firms to distant markets. Authors ask the following questions: (1) What is the current state of internationalisation of Polish firms in Latin America, in both quantitative (i.e. value of exports and FDI) and qualitative terms (i.e. characteristics of key exporters and investors); (2) What are the main distance-related barriers to internationalisation of Polish firms in Latin America. In order to describe the scale, scope and characteristics of Polish exports and investments in Latin America, authors analyse publicly available information, macro-level data and micro-level data, collected from the press and financial statements of Polish firms present in Latin America, combined with the information received from the Trade and Investment Promotion Sections of the Polish Embassies. In order to assess the distance between Poland and Latin America, thus indicating the major barriers to internationalisation of Polish firms in this region, the psychic distance measures elaborated by Hakanson and Ambos and the CAGE framework offered by Ghemawat are employed. This paper contributes to the discussion on whether the 'go global' strategy is viable for Polish firms and whether it should be supported by the State.

Keywords: internationalisation, distance, Poland, Latin America JEL Code: M16 


\section{Introduction}

Polish firms typically start their internationalisation process, and continue their expansion, in the markets proximate to Poland ${ }^{1}$. As a result, the geographical structure of Polish trade and foreign direct investment (FDI) is not diversified. In 2015, 89\% of Polish exports went to Europe and Central Asia, with top ten trading partners (i.e. Germany, Czech Republic, UK, France, Italy, Netherlands, Russian Federation, Sweden, Spain and Hungary) accounting for $66 \%$ of Polish exports ${ }^{2}$. Europe accounted for $88 \%$ of Polish outward FDI stock in 2015. The main recipients of Polish outward FDI in 2015 were Cyprus, Luxembourg, Czech Republic, Netherlands and Switzerland, although, except for Czech Republic, these investments typically were not productionor sales-oriented. In terms of the number of investment projects (both greenfield and $M \& A$ ), the most popular destinations of Polish ventures abroad are Germany, Lithuania, Czech Republic and $\mathrm{UK}^{3}$. In 2014, 61.4\% of foreign subsidiaries of Polish firms were located in the European Union (EU) ${ }^{4}$.

Thus, Polish firms follow the path of 'regional multinationals's , and very rarely reach out to global (i.e. outside the EU) markets. This strategy is in line with both the Uppsala model of internationalisation (at the early stage of internationalisation firms limit their international presence to psychically-close markets $)^{6}$, as well as the studies on performance outcomes of 'regional' versus 'global' MNCs. The latter stream of research indicates that home region-focused expansion yields faster growth that geographically dispersed expansion path ${ }^{7}$. The international behaviour of Polish firms

1 W. Nowiński, W. Nowara, Stopień i uwarunkowania internacjonalizacji polskich malych i średnich przedsiębiorstw, "Gospodarka Narodowa” 2011, vol. 3, pp. 29-45; R. Sliwiński, Zróżnicowanie przestrzenne i strategie internacjonalizacji polskich przedsiębiorstw, "Przegląd Organizacji" 2012, vol. 4, pp. 15-19; M. Jarosiński, Procesy i modele internacjonalizacji polskich przedsiębiorstw, SGH, Warsaw 2013.

2 World Bank, World Integrated Trade Solution, http://data.worldbank.org/data-catalog/wits (28.10.2016).

3 Ministerstwo Rozwoju, Polskie bezpośrednie inwestycje zagraniczne w 2014 roku, https://www. mr.gov.pl/media/18110/Polskie_inwestycje_bezposrednie_2014.pdf (3.11.2016).

4 Central Statistical Office, Działalność podmiotów posiadających jednostki zagraniczne w latach 2008-2014, Warsaw 2016.

5 A.M. Rugman, C. Bain, Multinational Enterprises Are Regional, Not Global, "Multinational Business Review" 2003, vol. 11(1), pp. 3-12.

6 J. Johanson, J.-E. Vahlne, The Internationalisation Process of the Firm - A Model of Knowledge Development and Increasing Foreign Market Commitments, "Journal of International Business Studies" 1977, vol. 8(1), pp. 23-32.

7 A.M. Rugman et al., Note on Return on Foreign Assets and Foreign Presence for UK Multinationals, "British Journal of Management" 2008, vol. 19(2), pp. 162-170. 
is also consistent with the International Business (IB) literature, indicating the crucial role of distance in shaping the firms' internationalisation strategy $y^{8}$.

Most of the IB studies conducted in Poland focus on 'typical' patterns of internationalisation and investigate firms operating in regional markets ${ }^{9}$. Recently, there have been numerous calls to diversify the structure of Polish exports and FDI, increasing the presence of Polish firms in the global (as opposed to purely regional) markets ${ }^{10}$. These calls have been supported by a number of initiatives sponsored by the Polish government. In 2012, the Polish Ministry of Economy initiated two programmes aimed at increasing the global presence of Polish firms: Go China and Go Africa ${ }^{11}$. One of the key goals of the Polish government for 2016 involved further diversification of export, measured by the increase in the share of export to distant markets (i.e. outside the EU) in the total Polish export ${ }^{12}$. Mexico has been chosen as one of the five key markets where the Polish government will conduct an intensive promotion of Polish industries ${ }^{13}$. Another initiative aimed at increasing the presence of Polish firms in distant markets, is the governmental Programme of Financial Support for Exporters $^{14}$. This programme, realised through the state development bank BGK, involves support for Polish firms on high-risk markets, based on an assumption of risk-sharing between the company expanding abroad and BGK.

'The calls for Polish firms 'going global' have not been followed by academic research, focusing on the opportunities and barriers to internationalisation in regard to distant markets. This paper aims at addressing this research gap, by focusing on the activities of Polish firms in one of the 'distant' regions, that is Latin America.

8 P. Ghemawat, Distance Still Matters: The Hard Reality of Global Expansion, "Harvard Business Review" 2001, vol. 79(8), pp. 137-147.

9 See for example: K. Wach, Europeizacja małych i średnich przedsiębiorstw: rozwój przez umiędzynarodowienie, Wydawnictwo Naukowe PWN, Warsaw 2012.

${ }^{10} \mathrm{~A}$. Arendarski, Polscy przedsiębiorcy w UE. 10 lat doświadczeń wobec wyzwań przyszłości, "Bezpieczeństwo Narodowe" 2014, vol. 4, pp. 125-137; B. Góralczyk, Stawiajmy na wschodzqqee rynki, "Obserwator Finansowy", 27.04.2015, https://www.obserwatorfinansowy.pl/tematyka/makroekonomia/stawiajmy-na-wschodzace-rynki/ (15.10.2016).

11 Polish Institute of International Affairs, Promocja polskiej gospodarki za granica, https://www. pism.pl/files/?id_plik=17520 (15.10.2016).

12 Ministerstwo Rozwoju, Plan działalności Ministra Rozwoju na rok 2016, http://mr.bip.gov.pl/ plan-dzialalnosci-ministerstwa/plan-dzialalnosci-na-2016-r.html (4.11.2016).

${ }^{13}$ Ministerstwo Rozwoju, Programy promocji na rynkach perspektywicznych, https://www.mr.gov. $\mathrm{pl} /$ strony/zadania/wspolpraca-miedzynarodowa/wspolpraca-gospodarcza/promocja-eksportu/\#Programy\%20promocji\%20na\%20rynkach\%20perspektywicznych (4.11.2016).

${ }_{14}$ BGK, Financial Support for Exporters. Government Programme, Warsaw 2015, https://www.bgk. pl/files/public/Pliki/Przedsiebiorstwa/Government_Programme_Financial_Support_for_Exporters.pdf (15.10.2016). 
Despite its economic potential ${ }^{15}$, and ethnic Polish minorities active in this region ${ }^{16}$, the presence of Polish firms in Latin America is very limited. In 2015 the region accounted for only $0,86 \%$ of Polish export and $0,87 \%$ of Polish outward FDI stock ${ }^{17}$.

In this paper the following questions are being asked: (1) What is the current state of internationalisation of Polish firms in Latin America, in both quantitative (i.e. value of exports and FDI) and qualitative terms (i.e. characteristics of key exporters and investors)?; (2) What are the main distance-related barriers to internationalisation ${ }^{18}$ of Polish firms in Latin America? Our contribution to the IB literature is twofold. First, on a theoretical level, we shed light on the understudied phenomenon of the expansion of Polish firms to very distant markets, providing a better understanding of the role of distance in the internationalisation process. Second, on a practical level, we contribute to the discussion on whether the 'go global' strategy is viable for Polish firms and whether it should be supported by the public policy measures. The article is structured as follows. First, the literature review is presented and theoretical foundations for the study are provided. Next, the research methods are being discussed. Then, the reader is being acquainted with the results of the conducted analyses. The theoretical and practical implications of the findings and the limitations of the study are also being discussed.

${ }_{15}$ K. Brudzińska, B. Znojek, Poland and Brazil: Narrowing the Distance, Exploring Mutual Potential, Policy Paper no. 46, Polish Institute of International Affairs, Warsaw 2012; P. Pazarán, México y Polonia, socios estratégicos, "Fortuna", 18.12.2012; B. Znojek, Emerging Latin America: A Case for Increasing Poland's Interest in the Region, PISM Strategic File no. 25, Polish Institute of International Affairs, Warsaw 2012; K. Brudzińska, M. Rostowska, Latin America and the Caribbean Countries and Central-Eastern Europe - Potential for Economic Cooperation: Polish Case Study, EU-LAC Foundation, Polish Institute of International Affairs, Warsaw 2014.

${ }^{16}$ M. Gorynia et al., Fostering Competitiveness of Polish Firms: Some Musings on Economic Policy and Spacial Expansion, in: International Management Development Research Yearbook, eds. E. Kaynak, T. Harcar, IMDA, Pennsylvania 2005; K. Brudzińska, Visão Geral das Relações Polônia-Brasil, "A União Europeia Alargada em tempos de novos desafios", pp. 163-174, Fundação Konrad Adenauer Stiftung, Rio de Janeiro 2014.

17 National Bank of Poland, Polskie inwestycje bezpośrednie za granica, http://www.nbp.pl/home. aspx?f=/publikacje/pib/pib.html (28.10.2016).

${ }^{18}$ IB literature indicates a number of barriers to internationalization, typically differentiating between internal (i.e. firm-specific, related to the company's strategy and resources) and external (i.e. environmental-specific, related to the conditions in the target market and the home country context), for details see for example: L.C. Leonidou, Empirical Research on Export Barriers: Review, Assessment, and Synthesis, "Journal of International Management" 1995, vol. 3(1), pp. 29-43. 


\section{Role of Distance in the Internationalisation Process}

Theories of foreign trade and International Business are based on the assumption that the location of home and host markets, and the resulting distance between them, play a fundamental role in shaping the internationalisation process and its outcomes. The macro-level gravity models of trade, posit that the geographic distance between two countries is a key determinant of the value of trade between these countries ${ }^{19}$. The micro-level IB theories assume that the 'liability of foreignness', resulting from operating in the unfamiliar market, is the key barrier to firm's internationalisation ${ }^{20}$. They also point to the fact that there are many sources of 'liability of foreignness', other than purely geographic distance, such as differences in language, education, business practices, level of economic development ${ }^{21}$, national culture ${ }^{22}$, institutional and political environment ${ }^{23}$, etc. Thus, the concept of distance is multidimensional and may not be reduced to geographical distance only.

A multidimensional framework of distance has been offered by Ghemawat ${ }^{24}$. His model is called CAGE, which is an acronym for: cultural, administrative, geographic, economic dimension of distance. Cultural distance refers to differences in language, religion and norms and values ${ }^{25}$. Extant research reveals that cultural distance increases the pressure on local responsiveness (as opposed to global integration) ${ }^{26}$, thus motivating firms to adapt their marketing $\mathrm{mix}^{27}$. Findings relating to the role of cultural distance in other internationalisation choices (e.g. market selection, mode of entry) and their outcomes, have been inconclusive. For example, Edwards and Buckley ${ }^{28}$ revealed that cultural proximity was the main attractor for Australian firms entering

${ }^{19} \mathrm{~J}$. Tinbergen, Shaping the World Economy: Suggestions for an International Economic Policy, New York 1962.

${ }^{20}$ S.H. Hymer, The International Operations of National Firms: A Study of Direct Foreign Investment, MIT Press, Cambridge 1976.

21 J. Johanson, J.-E. Vahlne, op. cit.

22 B. Kogut, H. Singh, The Effect of National Culture on the Choice of Entry Mode, "Journal of International Business Studies" 1988, vol. 19(3), pp. 411-432.

${ }^{23}$ H. Barkema et al., Foreign Entry, Cultural Barriers and Learning, "Strategic Management Journal" 1996, vol. 17(2), pp. 151-166.

${ }^{24}$ P. Ghemawat, op. cit.

${ }^{25}$ Ibidem.

26 C. A. Bartlett, S. Ghoshal, Managing Across Borders: The Transnational Solution, Harvard Business School Press, Boston 1989.

27 T.W. Moon, S. Park, The Effect of Cultural Distance on International Marketing Strategy: An Comparison of Cultural Distance and Managerial Perception Measures, "Journal of Global Marketing" 2011, vol. 24(1), pp. 18-40.

${ }^{28}$ R.W. Edwards, P.J. Buckley, Choice of Location and Mode: The Case of Australian Investors in the U.K., "International Business Review" 1998, vol. 7(5), pp. 503-520. 
UK, whereas Robertson and Wood ${ }^{29}$ found cultural distance to be the least important determinant of location choice. In a similar vein, there are studies revealing that high cultural distance increased the likelihood of choosing full-control modes of entry, that is wholly owned subsidiaries ${ }^{30}$, increased the likelihood of choosing joint ventures ${ }^{31}$ or did not affect the choice of entry mode ${ }^{32}$. Studies on the performance outcomes of internationalisation to culturally distant countries, again, yielded mixed results ${ }^{33}$.

Inconsistencies in findings relating to the role of cultural distance in internationalisation have been explained by difficulties in measuring national culture, and consequently, cultural distance. In IB literature, cultural distance is typically measured with the Kogut and Singh's ${ }^{34}$ index, based on dimensions offered by Hofstede ${ }^{35}$. Originally, the Hofstede framework, developed based on IBM database, covering 64 countries and created in 1967-1973, included four dimensions: power distance, uncertainty avoidance, individualism (vs. collectivism) and masculinity (vs. feminity). Recently, the Hofstede framework has been severely criticised both by psychologists ${ }^{36}$ and IB scholars $^{37}$, and there have been calls to use more modern approaches to measure culture, one of them being the GLOBE project ${ }^{38}$.

Administrative distance encompasses differences in administrative systems (resulting, for example, from the lack of colonial ties), currency, participation in international organisations and agreements (e.g. free market agreements). It is also determined by the level of political proximity and increases if the countries are politically hostile ${ }^{39}$. Administrative distance is strictly related to institutional distance ${ }^{40}$, and both terms

${ }^{29}$ K. R. Robertson, V. Wood, The Relative Importance of Type of Information in the Foreign Market Selection Process, "International Business Review" 2001, vol. 10(3), pp. 363-379.

${ }^{30}$ P. Padmanabhan, K.R. Cho, Ownership Strategy for a Foreign Affiliate: An Empirical Investigation of Japanese Firms, "Management International Review" 1996, vol. 36(1), pp. 45-65.

${ }^{31}$ K. Brouthers, L. Brouthers, Explaining the National Cultural Distance Paradox, "Journal of International Business Studies" 2001, vol. 32(1), pp. 177-189.

32 M.K. Erramilli, Nationality and Subsidiary Ownership Patterns in Multinational Corporations, "Journal of International Business" 1996, vol. 27(2), pp. 225-248.

${ }^{33}$ H. Barkema et al., op. cit.; P. Morosini, National Cultural Distance and Cross-Border Acquisition Performance, "Journal of International Business Studies" 1998, vol. 29(1), pp. 137-158.

34 B. Kogut, H. Singh, op. cit.

35 G. Hofstede, Culture's Consequences: Comparing Values, Behaviors, Institutions, and Organizations Across Nations, Sage, London 2011.

${ }_{36}$ P. Boski, Kulturowe ramy zachowań społecznych, Wydawnictwo Naukowe PWN, Warszawa 2009.

37 O. Shenkar, Cultural Distance Revisited: Towards a More Rigorous Conceptualization and Measurement of Cultural Differences, "Journal of International Business Studies" 2001, vol. 32(3), pp. 519-535.

38 R.J. House, Culture, Leadership, and Organizations, the Globe Study of 62 Societies, Sage, Thousand Oaks 2004.

39 P. Ghemawat, op. cit.

${ }^{40}$ T. Kostova, S. Zaheer, Organizational Legitimacy Under Conditions of Complexity: The Case of the Multinational Enterprise, "Academy of Management Review" 1999, vol. 24(1), pp. 64-81. 
are often used interchangeably ${ }^{41}$. The concept of institutional distance, grounded in institutional theory, relates to the differences in regulative, normative and cognitive institutions $s^{42}$ or, in other words, formal and informal institutions ${ }^{43}$. In IB research, institutional distance is typically measured with the use of Worldwide Governance Indicators, encompassing six dimensions: voice and accountability, political stability and absence of violence, government effectiveness, regulatory quality, rule of law, control of corruption ${ }^{44}$. Existing research reveals that administrative distance plays a crucial, yet often underestimated, role in export strategy. Frankel and Rose $\mathrm{e}^{45}$ indicate that, while common frontier (corresponding to 'geographic distance') and common language (corresponding to 'cultural distance') increase the trade between two countries by $80 \%$ and $200 \%$ respectively, administrative factors such as common currency and former colonial ties increase the volume of trade by $340 \%$ and $900 \%$ respectively. Administrative distance is also important to FDI. Firms entering markets with high institutional distance prefer joint ventures over full control entry modes and are less likely to pursue the strategy of global integration ${ }^{46}$ (as opposed to local responsiveness). Institutional distance is particularly relevant to developed market firms entering emerging markets, characterised by 'institutional voids ${ }^{47}$.

Geographic dimension of the CAGE model corresponds to the geographic distance concept included in the gravity models of foreign trade. It is typically measured as a distance between the capitals of two countries ${ }^{48}$. However, Ghemawat ${ }^{49}$ points to the fact that this dimension encompasses also differences in time zones, climate and diseases, as well as the lack of common border. Extant research reveals that, despite the fact that transportation and communication costs decrease, geographic distance

${ }^{41}$ M. Ciszewska-Mlinarič, A. Wąsowska, Znaczenie dystansu w procesie internacjonalizacji przedsiębiorstw, "Management and Business Administration. Central Europe" 2012, vol. 6(119), pp. 3-22.

${ }^{42}$ W. R. Scott, Institutions and Organization. Ideas, Interests, and Identities, Sage, Los Angeles-London-New Delhi-Singapore-Washington 2014.

43 D.C. North, Institutions, Institutional Change and Economic Performance, Cambridge University Press, Cambridge 1990.

${ }^{44}$ D. Kaufmann, A. Kraay, M. Mastruzzi, The Worldwide Governance Indicators: Methodology and Analytical Issues, The World Bank, Policy Research Working Paper no. 5430, 2010.

$45 \mathrm{~J}$. Frankel, A. Rose, An Estimate of the Effect of Common Currencies on Trade and Income, "Quarterly Journal of Economics" 2002, vol. 117(2), pp. 437-466.

${ }^{46}$ D. Xu, The Effect of Institutional Distance on Multinational Enterprise Strategy, Unpublished doctoral thesis, York University, Toronto 2001.

47 T. Khanna, K. Palepu, Winning in Emerging Markets, Harvard Business Press, Boston 2010.

${ }^{48}$ A. Cieślik, International Trade Under Monopolistic Competition: Evidence from Polish Bilateral Trade Data, European Trade Study Group, Warsaw 2006, http://www.etsg.org/ETSG2006/papers/cieslik. pdf (25.10.2016).

${ }^{49}$ P. Ghemawat, op. cit. 
still plays an important role in firms internationalisation strategy. Hummels ${ }^{50}$ found that $25 \%$ of world trade is conducted between countries sharing a border, and $50 \%$ - between countries located at a distance of less than 3000 kilometres. While geographic distance constitutes an important barrier to export, its impact upon FDI is less clear. On the one hand, FDI in distant countries may serve as an alternative to export, limiting the transportation costs. On the other hand, geographic distance increases the costs of conducting business abroad (e.g. monitoring costs), thus decreasing the volume of FDI ${ }^{51}$. Boeh and Beamish ${ }^{52}$ revealed that the choice of target market and entry mode is determined not by distance measured in kilometres, but rather by travel time. Moreover, they proved that long travel time between headquarters and subsidiary motivates companies to pursue joint ventures, in order to limit the monitoring costs.

Economic distance relates to the differences in the level of economic development, reflected in the costs of factors of production (especially labour) and the availability of technology $y^{53}$. The concept of economic distance, though implicitly included in technological theories of foreign trade, such as the Vernon's ${ }^{54}$ model, has rarely been explicitly used in IB studies ${ }^{55}$. In one of the few studies applying this concept, Makino et al. ${ }^{56}$ revealed that companies investing in countries with lower level of economic development exploit their existing resources (e.g. knowledge) and seek access to natural resources, while companies entering more developed markets explore new resources (e.g. seek new technologies). In a follow-up study building upon the findings of Makino et al. ${ }^{57}$, Tsang and Yip ${ }^{58}$ investigated the impact of economic distance upon FDI performance. They revealed that high economic distance contributes to better performance, since it allows one to achieve benefits resulting

50 D. Hummels, Transportation Costs and International Trade in the Second Era of Globalization, "Journal of Economic Perspectives" 2007, vol. 21(3), pp. 131-154.

${ }_{51}$ D.L. Carr et al., Estimating the Knowledge-Capital Model of the Multinational Enterprise, "American Economic Review" 2001, vol. 91(3), pp. 693-708.

${ }^{52} \mathrm{~K}$. Boeh, P. Beamish, Travel Time and the Liability of Distance in Foreign Direct Investment: Location Choice and Entry Mode, "Journal of International Business Studies" 2012, vol. 43(5), pp. 525-535.

53 P. Ghemawat, op. cit.

${ }_{54} \mathrm{R}$. Vernon, International Investment and International Trade in the Product Cycle, "Quarterly Journal of Economics" 1966, vol. 80(2), pp. 190-207.

55 M. Ciszewska-Mlinarič, A. Wąsowska, op.c it.

${ }^{56}$ S. Makino et al., Asset-Exploitation Versus Asset-Seeking: Implications for Location Choice of Foreign Direct Investment from Newly Industrialized Economies, "Journal of International Business Studies" 2002, vol. 33(3), pp. 403-421.

57 Ibidem.

${ }^{58}$ E. Tsang, P. Yip, Economic Distance and the Survival of Foreign Direct Investment, "Academy of Management Journal" 2007, vol. 50(5), pp. 1156-1168. 
from exploitation (in less developed countries) or exploration (in more developed countries) of resources.

The CAGE framework describes the 'objective' differences between two countries, measurable based on macro-level data. However, it has been argued that decisions in the internationalisation process are driven by the 'psychic distance', that is differences between two countries, subjectively perceived by decision-makers ${ }^{59}$. 'Objective' differences, encapsulated by the CAGE framework play a role of 'psychic distance stimuli' ${ }^{60}$, that is, they strongly influence the 'subjectively' perceived distance. Psychic distance has been defined as 'distance between the home market and a foreign market, resulting from the perception of both cultural and business differences ${ }^{3}$. Thus, psychic distance is multidimensional, and encompasses differences in culture, political systems, economic development ${ }^{62}$, religion, language ${ }^{63}$, etc. Moreover, it does not refer to 'objective' differences between the countries, but rather to the perception of these differences by decision-makers (i.e. managers and entrepreneurs). A large body of research on the antecedents and consequences of psychic distance, recently reviewed by Ciszewska-Mlinarič and Trąpczyński ${ }^{64}$, indicates that psychic distance influences market selection, modes of entry, sequence and speed of internationalisation, international strategy (e.g. the level of market adaptation) and performance outcomes of internationalisation.

\section{Research Methods}

'Latin America' consists the group of 20 countries having Romance language (Spanish, Portuguese or French) as their dominant languages, i.e. Argentina, Bolivia, Brazil, Chile, Colombia, Costa Rica, Cuba, Dominican Republic, Ecuador, El Salvador, Guatemala, Haiti, Honduras, Mexico, Nicaragua, Panama, Paraguay, Peru, Uruguay,

${ }_{59}$ M. Ciszewska-Mlinarič, P. Trąpczyński, The Psychic Distance Concept: A Review of 25 Years of Research (1990-2015), "Journal of Management and Business Administration. Central Europe" 2016, vol. 24(2), pp. 2-31.

${ }^{60}$ D. Dow, A. Karunaratna, Developing a Multidimensional Instrument to Measure Psychic Distance Stimuli, "Journal of International Business Studies" 2006, vol. 37(5), pp. 578-602.

${ }^{61}$ J. Evans, F. Mavondo, Psychic Distance and Organizational Performance: An Empirical Examination of International Retailing Operations, "Journal of International Business Studies" 2002, vol. 33(3), pp. 515-532.

${ }^{62} \mathrm{~J}$. Johanson, J.-E. Vahlne, op. cit.

${ }^{63}$ N. Boyacigiller, The Role of Expatriates in the Management of Interdependence, Complexity and Risk in Multinational Corporations, "Journal of International Business Studies" 1990, vol. 21(3), pp. 357-381.

${ }^{64}$ M. Ciszewska-Mlinarič, P. Trąpczyński, op. cit. 
Venezuela $^{65}$. In order to describe the scale, scope and characteristics of Polish exports and investments in Latin America, data from various sources is combined. First, macro-level statistics on trade and investment available from the General Statistics Office and the National Bank of Poland are used. Second, detailed information on the activities of Polish firms in Brazil and Argentina, provided to the author by the Trade and Investment Promotion Sections of the Polish Embassies in respective countries is used. Third, this information is compiled with data obtained through desk research, based on the review of Polish and foreign press and companies' websites and financial statements.

In order to assess the distance between Poland and Latin America, thus indicating the major barriers to internationalisation of Polish firms in this region, we employ the psychic distance measures elaborated by Hakanson and $A \operatorname{mbos}^{66}$ and a framework offered by Ghemawat ${ }^{67}$. In order to assess the cultural dimension of distance, the measures by Hofstede ${ }^{68}$ and GLOBE ${ }^{69}$ are used, and differences in language and religion are discussed, as well as the role of Polish diaspora in Latin America. In order to assess the administrative dimension of distance, the Worldwide Governance Indicators ${ }^{70}$ are used. A brief overview of institutional relationships between Poland and Latin America (e.g. economic diplomacy) is also presented. The geographic dimension of distance using the number of kilometres and travel time is assessed. In order to assess the economic distance, the GDP per capita and the GINI Index are used. Due to unavailability of data, in some cases the number of used Latin American countries in the research is being limited (e.g. Hofstede's scores are available only for 13 Latin American countries).

\section{Results and Discussion}

\subsection{Activities of Polish Firms in Latin America}

In 2015, Polish export to Latin America amounted to 1675720 thousand USD. Polish stock of FDI in Latin America amounted to 207788 thousand USD (Table 1).

65 CEPAL, Anuario Estadístico de América Latina y el Caribe, Santiago de Chile 2014.

${ }^{66}$ L. Hakanson, B. Ambos, The Antecedents of Psychic Distance, "Journal of International Management” 2010, vol. 16(3), pp. 195-210.

${ }^{67}$ P. Ghemawat, op. cit.

${ }^{68} \mathrm{G}$. Hofstede, op. cit.

${ }^{69}$ R.J. House et al., op. cit.

${ }^{70}$ World Bank, Worldwide Governance Indicators, http://info.worldbank.org/governance/wgi/index. aspx\#home (2.11.2016). 
Two largest Polish trade partners in Latin America are Brazil and Mexico. In 2015, Polish export to Brazil amounted to 397.6 million USD (25\% decrease in comparison to 2014 $)^{71}$ and included mostly fertilisers, rubber, telecommunications equipment and parts and accessories of the motor vehicles ${ }^{72}$. The decrease in Polish-Brazilian trade was due to economic crisis in Brazil, combined with high duties and complicated import procedures in this country. Polish export to Mexico amounted to 653.6 million USD and included mostly telecommunications equipment, parts and accessories of the motor vehicles, parts of furniture, razors, video games consoles, trucks, small aircraft, pharmaceuticals ${ }^{73}$. Polish export to Panama included mostly machinery and transport equipment and chemicals ${ }^{74}$. Except for Brazil, Mexico and Panama, the annual volume of Polish export to Latin American countries does not exceed 100 million USD per country. One of the destination with high potential for future development of Polish export is Chile, where an increased activity of Polish cosmetic industry is observed $\mathrm{d}^{75}$.

Table 1. Polish exports and FDI to Latin America (in thousand USD)

\begin{tabular}{|l|r|r|r|r|}
\hline \multicolumn{1}{|c|}{ Partner Name } & Export in 2010 & Export in 2015 & FDI stock in 2010 & FDI stock in 2015 \\
\hline Argentina & 82843 & 93142 & 5300 & 615 \\
\hline Bolivia & 873 & 6941 & 0 & 0 \\
\hline Brazil & 368135 & 397642 & 21900 & 34195 \\
\hline Chile & 54903 & 94152 & 4200 & 147676 \\
\hline Colombia & 21769 & 65263 & 1500 & -692 \\
\hline Costa Rica & 6462 & 12081 & 200 & 0 \\
\hline Cuba & 11678 & 54825 & 1100 & 1102 \\
\hline Dominican Republic & 3326 & 9583 & 0 & 0 \\
\hline Ecuador & 11394 & 9795 & 0 & 0 \\
\hline El Salvador & 610 & 1283 & 0 & 0 \\
\hline Guatemala & 3102 & 4370 & 0 & 0 \\
\hline Haiti & 2284 & 3378 & 0 & 0 \\
\hline Honduras & 697 & 1646 & 0 & 11792 \\
\hline Mexico & 267439 & 653591 & 19900 & 0 \\
\hline Nicaragua & 207 & 2373 & -5400 & 0 \\
\hline
\end{tabular}

${ }^{71}$ World Bank, World Integrated Trade Solution, http://data.worldbank.org/data-catalog/wits (28.10.2016).

72 Central Statistical Office, Yearbook of foreign trade statistics of Poland 2015, Warsaw 2016.

${ }^{73}$ Ibidem.

${ }^{74}$ World Bank, World Integrated Trade Solution, op, cit.

${ }^{75}$ El Economista, Empresas polacas salen a la conquista del mercado de la belleza en Chile, 15.10.2015. 


\begin{tabular}{|l|c|c|c|c|}
\hline \multicolumn{1}{|c|}{ Partner Name } & Export in 2010 & Export in 2015 & FDI stock in 2010 & FDI stock in 2015 \\
\hline Panama & 23479 & 109089 & 9400 & 10664 \\
\hline Paraguay & 2257 & 6401 & 0 & 0 \\
\hline Peru & 32583 & 51380 & 1900 & 2307 \\
\hline Uruguay & 11433 & 7372 & 0 & 128 \\
\hline Venezuela & 23274 & 91413 & 1200 & 0 \\
\hline Total & 928748 & 1675720 & 61200 & 207788 \\
\hline
\end{tabular}

Source: own study based on World Bank and National Bank of Poland. See World Bank, World Integrated Trade Solution, op.cit. and National Bank of Poland, Polskie inwestycje bezpośrednie za granicg, http://www.nbp.pl/home. aspx?f=/publikacje/pib/pib.html (28.10.2016).

Most of the Polish export to Latin America is conducted by Polish subsidiaries of multinational corporations. For example, within 25 largest exporters to Brazil there are only 6 independent Polish companies: Medcom, Azoty, ND Service, ADOB, Selena and Synthos (Table 2). The remaining part of the largest exporters to Brazil are the Polish subsidiaries of multinational corporations, typically headquartered in Western Europe or US.

Table 2. Largest Polish exporters to Brazil

\begin{tabular}{|l|l|}
\hline Autorobot-Strefa (turnkey car body assembly lines) & $\begin{array}{l}\text { A joint-venture company, created as a result of } \\
\text { cooperation of Polish, Italian and Brazilian partners }\end{array}$ \\
\hline Faurecia-Automotive Polska (automotive parts) & Polish subsidiary of a French group \\
\hline $\begin{array}{l}\text { Flextronics International Poland (Flex) (electronics } \\
\text { manufacturing services) }\end{array}$ & $\begin{array}{l}\text { Polish subsidiary of an American group headquartered } \\
\text { in Singapore }\end{array}$ \\
\hline FLSMIDTH MAAG Gear (gear units) & Polish subsidiary of a Swiss group \\
\hline HTL-Strefa (medical devices) & $\begin{array}{l}\text { Polish-born company, currently owned by a Swedish } \\
\text { private equity fund EQT }\end{array}$ \\
\hline Klingspor (abrasive technology supplier) & Polish subsidiary of a German group \\
\hline Medcom (traction converters) & Polish firm \\
\hline Michelin Polska (tires) & Polish subsidiary of a French group \\
\hline Nidec Motors \&Actuators Poland (motors, actuators) & Polish subsidiary of a German group \\
\hline Arcelormittal Poland (steel) & $\begin{array}{l}\text { Polish subsidiary of an international group of Indian } \\
\text { origin, headquartered in Luxembourg }\end{array}$ \\
\hline Arjohuntleigh Polska (healthcare products) & Polish subsidiary of a Swedish group \\
\hline Durr Poland (production, process and measuring technology) & Polish subsidiary of a German group \\
\hline GE Power Controls (electrical components) & Polish subsidiary of an American group \\
\hline GlaxoSmithKline (pharmaceuticals) & Polish subsidiary of a British group \\
\hline Grupa Azoty S.A. (nitrogenous fertilisers) & Polish firm \\
\hline
\end{tabular}




\begin{tabular}{|l|l|}
\hline Hamilton Sundstrand Poland (aircraft engines) & Polish subsidiary of an American group \\
\hline Adama Polska (crop protection products) & Polish subsidiary of an Israeli group \\
\hline ND Service (power hydraulics, electrical systems) & Polish firm \\
\hline Nexteer Automotive Poland (steering and driveline systems) & Polish subsidiary of an American group \\
\hline PCC Rokita (chemical facilities) & Polish subsidiary of a German group \\
\hline Philips Lighting (lighting solutions) & Polish subsidiary of a Dutch group \\
\hline Przedsiębiorstwo Produkcyjno-Consultingowe ADOB & Polish firm \\
\hline Rosti (Polska) (plastic products) & Polish subsidiary of a Swedish group \\
\hline Selena FM (construction chemicals) & Polish firm \\
\hline Synthos Dwory (chemical raw materials) & Polish firm \\
\hline
\end{tabular}

Source: own study based on data provided by the Trade and Investment Promotion Section of the Polish Embassy in Brazil.

Polish FDI in Latin America is very low, both in terms of value (see Table 1) and the number of foreign ventures. In 2014, there were 29 subsidiaries of Polish firms in South America ${ }^{76}$. Polish FDI in Latin America focuses on Chile, Brazil, Mexico and Panamas offshore banking sector. However, Polish FDI in Chile is nearly exclusively attributable to one project: KGHM's investment in Sierra Gorda mine in 2012. Before this transaction, Polish stock of FDI in Chile did not exceed 5 million USD. In terms of the frequency of the investment projects, the most common destination of Polish FDI has been Brazil. Major foreign direct investments of Polish firms in Latin America are presented in Table 3.

Investment projects in Latin America have been conducted by mature firms, most of them well-established in the domestic market and in markets proximate to Poland. Moreover, some of them, before investing in Latin America, already had a significant export experience in this market (e.g. Synthos), and FDI experience in more proximate markets (e.g. Lug Group, Selena). Thus, it may be concluded, that key Polish investors in Latin America followed the Uppsala model of internationalisation ${ }^{77}$ : they gradually increased the distance and commitment to foreign markets and FDI in Latin America constituted a mature stage in their internationalisation lifecycles. However, even for large, experienced Polish firms, FDIs in Latin America are difficult, as evidenced by some failed (e.g. Ciech, City Interactive, FM Group, Nowy Styl, Synthos) or challenging (e.g. KGHM) projects.

${ }^{76}$ Central Statistical Office, Dzialalność podmiotów posiadających jednostki zagraniczne w latach 2008-2014, Warsaw 2016.

77 J. Johanson, J.-E. Vahlne, op. cit. 
Table 3. Major Polish investments in Latin America

\begin{tabular}{|c|c|c|c|}
\hline $\begin{array}{l}\text { Company } \\
\text { name }\end{array}$ & $\begin{array}{l}\text { Company } \\
\text { profile }\end{array}$ & $\begin{array}{c}\text { Investment } \\
\text { in Latin America }\end{array}$ & Activities in Latin America \\
\hline AC Stag & $\begin{array}{l}\text { Automotive } \\
\text { parts }\end{array}$ & Peru, 2014 & $\begin{array}{l}\text { The first Polish investment in Peru, the subsidiary is responsible for } \\
\text { sales of components and sets of autogas systems and automotive } \\
\text { electronics. }\end{array}$ \\
\hline $\begin{array}{l}\text { Boryszew } \\
\text { (Maflow) }\end{array}$ & $\begin{array}{l}\text { Auto, chemical } \\
\text { and metal parts } \\
\text { producer }\end{array}$ & $\begin{array}{l}\text { Brazil, } 2010 \\
\text { Mexico, } 2015\end{array}$ & $\begin{array}{l}\text { In } 2010 \text {, Boryszew acquired the Italian group Maflow, including its } \\
\text { Brazilian branch Maflow do Brazil Ltda. This company cooperates } \\
\text { with Brazilian and Argentinean factories of global car manufacturers } \\
\text { (e.g. WW, Fiat, GM, Nissan, PSA, Volvo). The company produces } \\
\text { automotive parts for car manufacturers located in Brazil and } \\
\text { Argentina (Volkswagen, Fiat, Nissan, Renault). In } 2015 \text { Boryszew } \\
\text { announced that it would open a factory in Mexico'. This investment } \\
\text { serves as a gate to the market of NAFTA }{ }^{b} \text {. }\end{array}$ \\
\hline Ciech & $\begin{array}{l}\text { Chemicals } \\
\text { (soda ash, } \\
\text { sodium } \\
\text { bicarbonate) }\end{array}$ & Brazil, 2007 & $\begin{array}{l}\text { The sales subsidiary registered in Brazil was responsible for } \\
\text { distribution in Latin America. In } 2009 \text { the company suspended its } \\
\text { activity. }\end{array}$ \\
\hline $\begin{array}{l}\text { City } \\
\text { Interactive }\end{array}$ & Video games & $\begin{array}{l}\text { Brazil, 2008; } \\
\text { Mexico, 2008; } \\
\text { Peru, } 2008\end{array}$ & $\begin{array}{l}\text { City Interactive, acquired shares of three companies located } \\
\text { in Peru, Brazil and Mexico with the objective of starting production } \\
\text { and distribution of games in Latin America. In } 2009 \text { the plan was } \\
\text { abandoned. }\end{array}$ \\
\hline Comarch & ICT & $\begin{array}{l}\text { Panama, 2004; } \\
\text { Chile, 2013; } \\
\text { Brazil, 2015; } \\
\text { Argentina, } 2015\end{array}$ & $\begin{array}{l}\text { Subsidiaries In Panama, Chile, Brazil and Argentina are responsible } \\
\text { for production and distribution of IT systems in Latin America. }\end{array}$ \\
\hline eSKY & $\begin{array}{l}\text { Online travel } \\
\text { agency }\end{array}$ & Brazil, 2011 & $\begin{array}{l}\text { The main motive of investment was market-seeking, the online } \\
\text { agency serves the Brazilian market. }\end{array}$ \\
\hline FM Group & Cosmetics & Brazil, 2009 & $\begin{array}{l}\text { The company was a pioneering Polish investor in Argentina. } \\
\text { However, due to import restrictions, in } 2013 \text { the company withdrew } \\
\text { from this market. }\end{array}$ \\
\hline Inglot & Cosmetics & Mexico, 2011 & $\begin{array}{l}\text { Inglot registered its subsidiary in Mexico for market-seeking } \\
\text { reasons, it also has its stores in Argentina, Chile, Colombia, Peru. }\end{array}$ \\
\hline KGHM & $\begin{array}{l}\text { Copper } \\
\text { producer }\end{array}$ & Chile, 2012 & $\begin{array}{l}\text { The largest Polish establishment in Latin America is KGHM's } \\
\text { investment in Sierra Gorda mine in Chile, performed via the } \\
\text { Canadian subsidiary Quadra (now: KGHM International). The main } \\
\text { motive of investment was resource-seeking. Due to the fact that } \\
\text { costs of extraction turned out to be higher than expected, the } \\
\text { investment is considered controversial and in } 2016 \text { the Polish } \\
\text { government announced that is would reconsider the viability of the } \\
\text { investment. }\end{array}$ \\
\hline Komandor & Furniture & Brazil, 2002 & $\begin{array}{l}\text { The Brazilian subsidiary, one of the first Polish investments in Brazil, } \\
\text { is responsible for distribution of furniture in the Brazilian market. }\end{array}$ \\
\hline Lug Group & $\begin{array}{l}\text { Electrical } \\
\text { equipment }\end{array}$ & $\begin{array}{l}\text { Brazil, 2012; } \\
\text { Argentina, } 2016\end{array}$ & $\begin{array}{l}\text { The Brazilian subsidiary serves as a regional centre for sales, } \\
\text { technical support, advisory and training. The investment in Argentina } \\
\text { will involve building a production facility and further increasing the } \\
\text { presence of Lug products in Latin America. }\end{array}$ \\
\hline
\end{tabular}




\begin{tabular}{|l|l|l|l|}
\hline $\begin{array}{c}\text { Company } \\
\text { name }\end{array}$ & \multicolumn{1}{|c|}{$\begin{array}{c}\text { Company } \\
\text { profile }\end{array}$} & $\begin{array}{c}\text { Investment } \\
\text { in Latin America }\end{array}$ & \multicolumn{1}{c|}{ Activities in Latin America } \\
\hline Medcom & $\begin{array}{l}\text { Equipment for } \\
\text { power supply } \\
\text { systems }\end{array}$ & Brazil, 2011 & $\begin{array}{l}\text { The company delivers solutions supporting public transport } \\
\text { systems (e.g. subway trains in Sao Paolo) and power supply } \\
\text { systems. }\end{array}$ \\
\hline Nowy Styl & Furniture & Mexico, 2001 & $\begin{array}{l}\text { One of the first Polish investments in Mexico, the subsidiary was } \\
\text { responsible for production and distribution of chairs, the activity was } \\
\text { abandoned, currently it is limited to supplying the Mexican partner } \\
\text { Kindemexe. }\end{array}$ \\
\hline Selena & $\begin{array}{l}\text { Construction } \\
\text { chemicals }\end{array}$ & Brazil, 2004 & $\begin{array}{l}\text { Selena Sulamericana serves mostly Brazilian market, but also } \\
\text { Argentina, Uruguay, Chile and Mexico. }\end{array}$ \\
\hline Synthos & $\begin{array}{l}\text { Chemical raw } \\
\text { materials }\end{array}$ & Brazil, 2013 & $\begin{array}{l}\text { In 2014 Synthos announced the plan to build a large rubber } \\
\text { factory in Brazil, in order to replace exports with FDI'. However, due } \\
\text { to problems with suppliers and an underestimation of investment } \\
\text { costs, the plan was abandoned in 2015. Synthos serves the } \\
\text { Brazilian market through exports. }\end{array}$ \\
\hline
\end{tabular}

${ }^{a}$ Maflow, Ya hemos llegado a México, http://www.maflow.es/ya-hemos-legado-mexico/ (15.10.2016).

'TVN24bis, Meksyk 'bramq' dla dużej polskiej firmy. Boryszew wziq̨ kredyt, by rozwijać się poza Polską, http:// tvn24bis.pl/z-kraju,74/boryszew-wzial-10-mln-euro-kredytu-w-bgk,551578.html (15.10.2016).

'I. Sudak, KGHM zrejteruje z Chile? Rekordowa polska inwestycja może zakończyć się klapa, "Gazeta Wyborcza", 25.10.2016.

"Protocolo, Polonia busca incrementar lazos con México, "Protocolo", 1.11.2002.

${ }^{e}$ Ministerstwo Rozwoju, Notatka informacyjna o polsko-meksykańskich stosunkach gospodarczych, 20.09.2016, https://www.mr.gov.pl/media/26597/Meksyk_20_09_2016.pdf (2.11.2016).

${ }^{\mathrm{f}} \mathrm{G}$. Lara, Polonesa Synthos vai investir até R\$ 640 milhões no RS, "Estadão", 26.01.2015.

Source: own study based on desk research.

\subsection{Distance-Related Barriers to Internationalisation of Polish Firms in Latin America}

\section{Cultural distance}

Latin America is often depicted as a homogeneous region ${ }^{78}$, with a common culture $^{79}$. A number of studies grouping national cultures based on values and attitudes have found that Latin American countries form a common cluster ${ }^{80}$. A detailed anal-

${ }^{78}$ S.M. Davis, United States Versus Latin America: Business and Culture, "Harvard Business Review" 1969, vol. 47(6), pp. 15-24.

${ }^{79}$ E.J. Romero, Latin American Leadership: el Patrón \& el Lider Moderno, "Cross Cultural Management: An International Journal" 2004, vol. 11, pp. 25-37.

${ }^{80} \mathrm{~S}$. Ronen, O. Shenkar, Clustering Countries on Attitudinal Dimensions: A Review and Synthesis, "Academy of Management Review" 1985, vol. 10, pp. 435-454; S. H. Schwartz, Value Orientations: Measurement, Antecedents and Consequences Across Nations, in: Measuring Attitudes Cross-National - Lessons from the European Social Survey, eds. R. Jowell et al., Sage, London 2006. 
ysis of cultural dimensions by Hofstede ${ }^{81}$ (see Figure 1) and GLOBE ${ }^{82}$ (see Figure 2) reveals, however, important heterogeneities between Latin American countries. Moreover, it enables to detect similarities and differences between Poland and Latin American countries.

\section{Figure 1. Hofstede's dimensions}

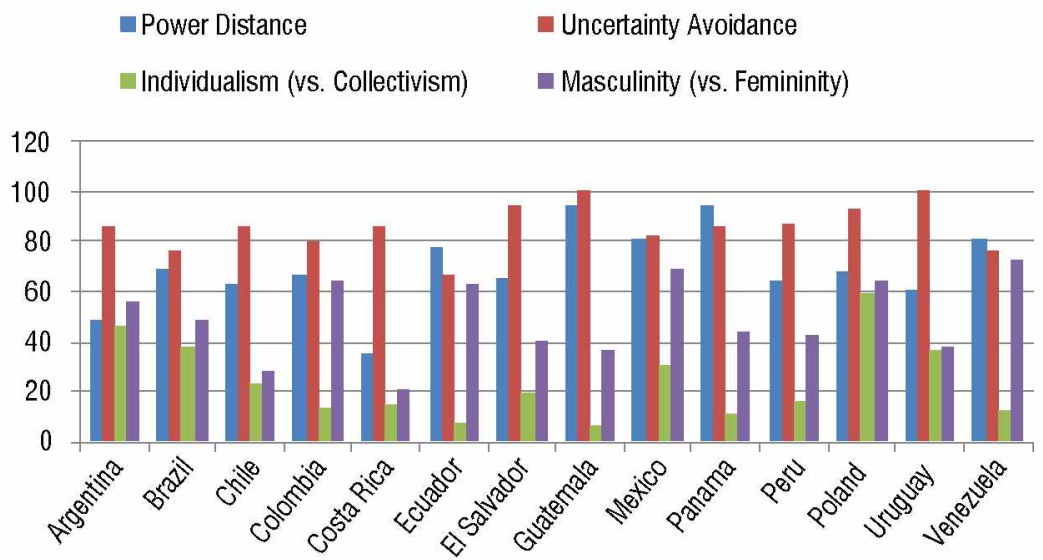

Source: own study based on Hofstede. See G. Hofstede, op. cit.

Power distance is defined as 'the extent to which the less powerful members of institutions and organisations within a country expect and accept that power is distributed unequally ${ }^{83}$. Poland and most of the Latin American countries (with the exception of Costa Rica and Argentina) score relatively high in this dimension. They are, therefore, hierarchical societies, where subordinates expect to be told what to do and an ideal boss is a 'benevolent autocrat'. Moreover, Latin American leadership is based on paternalism, i.e. 'making decisions for employees in a parental way that engenders care and loyalty, as well as protecting working relationships ${ }^{84}$. Paternalism has its roots in the 'hacienda' system, where the owner (patrón) 'lorded over the employees and their families ${ }^{35}$. Hierarchism related to high power distance is reflected in honorific expressions, used extensively in Polish ('Panie Dyrektorze', 'Panie Magistrze (...)', Spanish (Señor Director) and Portuguese ('O Senhor Doutor').

${ }^{81}$ G. Hofstede, op. cit.

82 R.J. House et al., op. cit.

${ }^{83}$ Ibidem.

${ }^{84}$ N. Castaño et al., El Jefe: Differences in Expected Leadership Behaviors Across Latin America, "Journal of World Business" 2015, vol. 50(3), pp. 584-597.

85 Ibidem. 
Individualism (vs. Collectivism) addresses 'the degree of interdependence a society maintains among its members ${ }^{36}$ and has to do with whether members of a society define themselves in terms of 'I' or 'We'. Latin American countries score rather low on this dimension, thus being collective societies, which manifests itself in long-term commitments to the group members (e.g. families, extended families, neighbourhoods) and loyalty towards a group over-riding other societal rules. Poland, in turn, is an individualistic society, and its members exhibit a preference towards loosely-knit social structure.

Uncertainty avoidance reflects the level of anxiety caused by a fact that the future is unknown, that is the extent to which members of a culture feel threatened by ambiguous, unknown situations ${ }^{87}$. Poland and the Latin American countries score high on this dimension, which indicates that these countries may share an 'emotional need for rules' (even if these rules are not respected) and intolerance of unorthodox beliefs and ideas. Uncertainty avoidance, in the Hofstede's interpretation, is grounded in historical experience of non-democratic regimes, protecting ideological purity (as opposed to democracy and pluralism).

Masculinity (vs. feminity) reflects the extent to which the society is driven by 'competition, achievement and success, with success being defined by the winner / best in field ${ }^{88}$. Poland and some of the Latin American (i.e. Venezuela, Mexico, Ecuador, Colombia) countries score high on this dimension, thus being masculine societies where emphasis is put on competition and performance, while managers are expected to be decisive and assertive. However, Latin America is a very heterogeneous region, with some countries scoring exceptionally low on masculinity. The most 'feminine' country in Latin America (and in the world) is Costa Rica. This is reflected by a general fear of personal criticism as well as high acceptance of women in business. 'Feminine' values (i.e. caring for the quality of life and the well-being of others) are also evidenced by the fact that Costa Rica wants to become the first carbon neutral country in the world.

The GLOBE Project constitutes an alternative to Hofstede's framework and describes national cultures on 9 dimensions ${ }^{89}$. The $1^{\text {st }}$ triad (performance orientation, future orientation and uncertainty avoidance) is presented in Figure 2. GLOBE indicates that Poland and Latin American countries rank low on performance orientation. Therefore, these societies do not encourage innovation, excellence and high standards ${ }^{90}$.

\footnotetext{
86 G. Hofstede, op. cit.

87 Ibidem.

88 Ibidem.

${ }^{89}$ R.J. House et al., op. cit.

90 Ibidem.
} 
Moreover, Poland and Latin American countries score very low on future orientation. The perception of time in Latin America is polichronic (as opposed to monochronic), i.e. numerous duties are dealt with simultaneously (not in a linear order), with many duties left aside, to be dealt with in the future (the concept of mañana). Related to future orientation is another dimension, i.e. uncertainty avoidance, on which Poland and Latin American countries score very low. Thus, these societies are characterised by disorder and lack of respect to rules and regulations ${ }^{91}$.

Figure 2. GLOBE dimensions (1st triad)

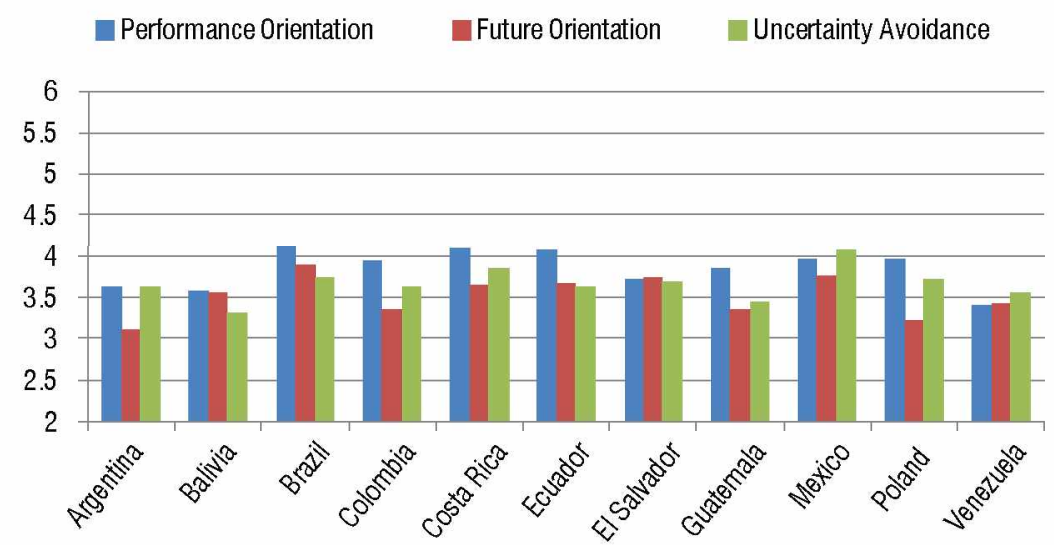

Source: own study based on GLOBE. See R.J. House et al., op. cit.

The $2^{\text {nd }}$ triad of GLOBE dimensions (power distance, in-group collectivism, institutional collectivism) is presented in Figure 3. The results for power distance are consistent with Hofstede's work and indicate that Poland and Latin American countries score relatively high on this dimension, with Poland scoring higher than Bolivia, Costa Rica and Mexico, and lower than the remaining Latin American countries under study. Moreover, Poland and Latin American countries score high on in-group collectivism, which indicates that members of these societies demonstrate pride, loyalty and cohesiveness in their families. Conversely, Poland and Latin American countries score medium-low on institutional collectivism, therefore, they do not value collective actions on a public level.

${ }^{91}$ According to Hofstede, 'uncertainty avoidance' for Poland and Latin America is exceptionally high, while according to GLOBE, it is exceptionally low. This inconsistence is due to fact that the definition and operationalisation of this dimension in the GLOBE Project is different than in Hofstede's work and moreover, the analysed dimension of GLOBE focuses on the aspect of cultural 'practices' (as opposed to cultural 'values'), see: P. Boski, op. cit. 
Figure 3. GLOBE dimensions ( $2^{\text {nd }}$ triad)

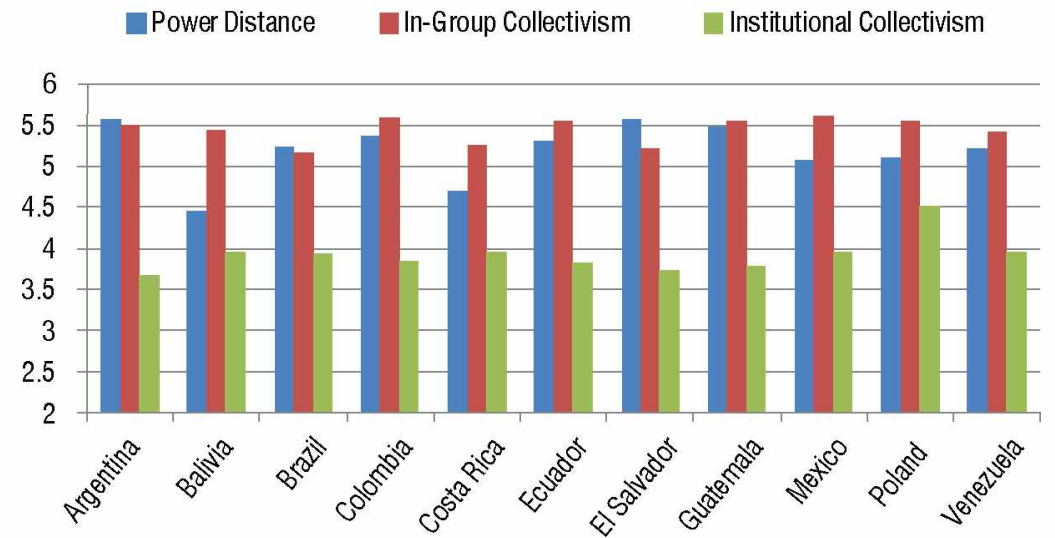

Source: own study based on GLOBE. See R.J. House et al., op. cit.

Figure 4. GLOBE dimensions ( $3^{\text {rd }}$ triad)

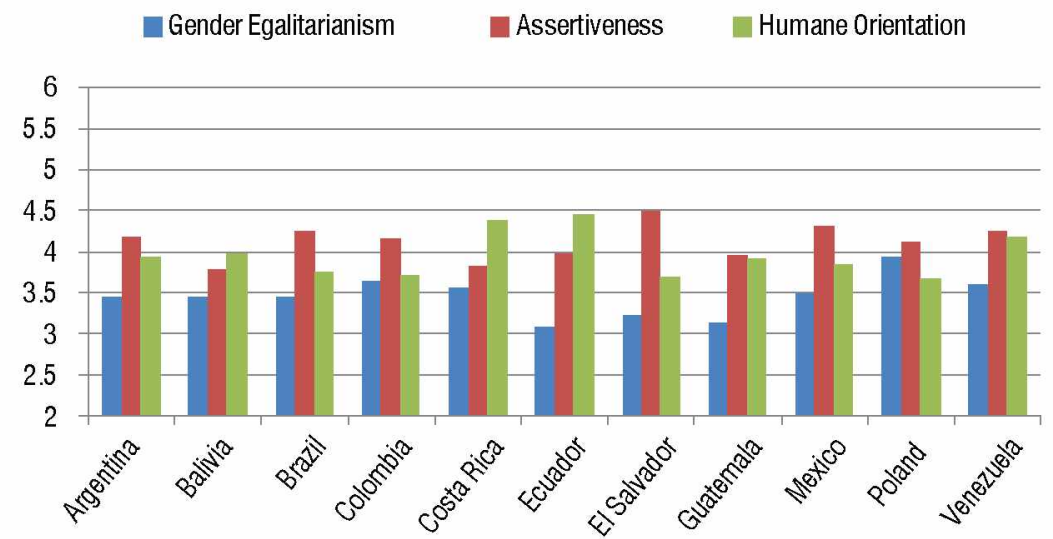

Source: own study based on GLOBE. See R.J. House et al., op. cit.

The $3 \mathrm{rd}$ triad of GLOBE dimensions is presented in Figure 4. Poland scores higher than all the Latin American countries under study on gender egalitarianism, defined as 'the degree to which a collective minimises gender inequality' ${ }^{\prime 2}$. In terms of assertiveness, defined as 'the degree to which individuals are assertive, confrontational, and aggressive in their relationships with others ${ }^{\prime 93}$, Poland and Latin American

92 Ibidem, p. 30 .
93 Ibidem, p. 30. 
countries rank medium to high, with Poland scoring lower than El Salvador, Brazil, Venezuela, Argentina and Colombia, and higher than Bolivia, Costa Rica, Ecuador and Guatemala. Poland scores lower than the Latin American countries (with the exception of El Salvador) on humane orientation, defined as 'the degree to which an organisation or society encourages and rewards individuals for being fair, altruistic, friendly, generous, caring, and kind to others ${ }^{294}$.

Apart from Hofstede and GLOBE cultural dimensions, cultural distance includes also language, religion and the effects of diaspora ${ }^{95}$. In all Latin American countries (excluding Brazil and Haiti), Spanish is the official language. In Brazil, it is Portuguese, while in Haiti it is French. The sole official language in Poland is Polish. The linguistic distance between Poland and Latin America can be bridged by the fact that Spanish is a popular language learned by non-native speakers, also in Poland. The number of people learning Spanish in Poland is estimated at 390 thousand $^{96}$. The number of students learning Spanish at the level of primary and secondary school amounts to 72 thousands ${ }^{97}$. Conversely, a factor that may contribute to an increased linguistic distance between Poland and Latin America is the fact that the command of English is rather poor in some Latin American countries. In terms of adult English proficiency, measured with the EF English Proficiency Index ${ }^{98}$, Poland scores very high ( $9^{\text {th }}$ position out of 70 countries), while the ranking positions of Latin American countries included in the study are as follows: Argentina - 15, Dominican Republic -24, Peru-35, Chile - 36, Ecuador - 38, Mexico - 40, Brazil - 40, Costa Rica - 43, Uruguay - 44, Guatemala - 46, Panama - 48, Colombia - 57, Venezuela - 59, El Salvador -61 .

Poland and Latin American countries share a common religion. In all Latin American countries Roman Catholicism, introduced by the Spanish and the Portuguese during the colonial era, remains the dominant faith. Latin America accounts for $40 \%$ of the World's total Catholic population, with Brazil being the largest Catholic population of any country (150 million Catholics) ${ }^{99}$. Another factor that is believed to contribute to the reduction of cultural distance between Poland and Latin America

94 Ibidem, p. 569.

95 P. Ghemawat, op. cit.

96 Instituto Cervantes, El español: una lengua viva. Informe 2013, http://cvc.cervantes.es/lengua/ anuario/anuario_13/i_cervantes/p01.htm (15.10.2016).

${ }_{97}$ M. Spychała, Kształcenie nauczycieli języka hiszpanskiego w Polsce i na świecie: wyzwania $i$ potrzeby edukacyjne, in: Nauczanie jezyków obcych na potrzeby rynku pracy, eds. M. Sowa et al., Wydawnictwo KUL, Lublin 2015.

98 EF English Proficiency Index, http://www.ef.pl/epi/ (3.11.2016).

99 World Christian Database, quoted by: BBC (2013), How Many Roman Catholics Are There in the World?, http://www.bbc.com/news/world-21443313 (3.11.2016). 
is the Polish diaspora ${ }^{100}$. Two major destinations of Polish migration in Latin America are Argentina and Brazil. According to the UN Global Migrant Origin Database ${ }^{101}$, covering national censuses and taking into account the country of birth, of in 2001, in Argentina there were 14150 Polish immigrants, the majority of which were over 65 years old. In 2010, the number of Polish immigrants to Brazil amounted to 3483 . Again, the majority of Polish immigrants were above 65 years old. In other Latin American countries the population of Polish immigrants is much smaller (see Table 4). The 'Polonia' organisations assess the size of Polish diaspora in Latin America, including the descendants of Polish immigrants, as much higher (e.g. 10000 in Mexico, 10000 in Uruguay, 10000 in Paraguay, 3000 in Venezuela, 3000 in Colombia, 5000 in Peru, 200 000-450 000 in Argentina and 80 000-3 000000 in Brazil) ${ }^{102}$.

Taking into account the shrinking of the population of Polish-born immigrants in Argentina and Brazil and the small Polish migrant stock in other Latin American countries, it may be concluded that the impact of Polish diaspora upon the cultural distance between Poland and Latin America is rather limited.

Table 4. Polish migrants stock in Latin America

\begin{tabular}{|l|c|c|l|c|c|}
\hline \multicolumn{1}{|c|}{ Country } & $\begin{array}{c}\text { Number of Polish } \\
\text { immigrants }\end{array}$ & Year* & \multicolumn{1}{|c|}{ Country } & $\begin{array}{c}\text { Number of Polish } \\
\text { immigrants }\end{array}$ & Year* \\
\hline Argentina & 14150 & 2001 & Guatemala & N/A & N/A \\
\hline Bolivia & 173 & 2001 & Haiti & N/A & N/A \\
\hline Brazil & 3483 & 2010 & Honduras & 3 & 2001 \\
\hline Chile & 432 & 2002 & Mexico & 849 & 2010 \\
\hline Colombia & 204 & 2005 & Nicaragua & 9 & 2005 \\
\hline Costa Rica & 227 & 2000 & Panama & 149 & 2010 \\
\hline Cuba & 94 & 2002 & Paraguay & 351 & 2002 \\
\hline Dominican Republic & 157 & 2002 & Peru & 180 & 2007 \\
\hline Ecuador & 130 & 2001 & Uruguay & 1473 & 1996 \\
\hline El Salvador & 5 & 2007 & Venezuela & 766 & 2001 \\
\hline
\end{tabular}

* Last census available

Source: own study based on UN Global Migrant Origin Database See United Nations, op. cit.

100 M. Gorynia et al., Fostering Competitiveness..., op. cit.

101 United Nations, UN Global Migrant Origin Database https:/esa.un.org/unmigration/index.aspx (15.10.2016).

102 Stowarzyszenie 'Wspólnota Polska', Polonia w liczbach, http://swp4.wspolnotapolska.org.pl/polonia_w_liczbach.html (15.10.2016). 


\section{Administrative distance}

In order to assess the administrative distance between Poland and Latin American countries, authors first review the Worldwide Governance Indicators (WGI) ${ }^{103}$ for these countries. Figure 5 presents first two indicators: voice \& accountability, which captures the 'perceptions of the extent to which country's citizens are able to participate in selecting their government, as well as freedom of expression, freedom of association, and free media' and political stability and absence of violence/terrorism, referring to the 'perceptions of the likelihood that the government will be destabilized or overthrown by unconstitutional or violent means, including politically motivated violence and terrorism ${ }^{104}$. In terms of voice \& accountability, Poland scores a little lower than Costa Rica and Uruguay, and higher than the remaining Latin American countries. In terms of political stability, Poland is outperformed only by Uruguay.

Figure 5. WGI - voice $\&$ accountability and political stability

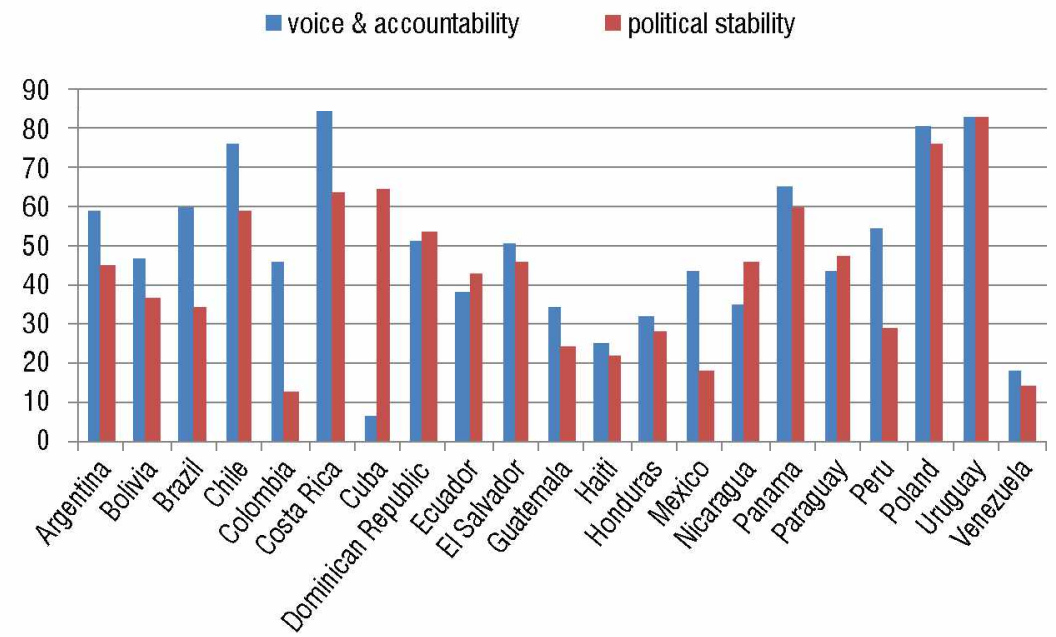

Source: own study based on World Bank. See World Bank, Worldwide Governance Indicators, op. cit..

Figure 6 presents another two indicators: government effectiveness, capturing 'perceptions of the quality of public services, the quality of the civil service and the degree of its independence from political pressures, the quality of policy formulation and implementation, and the credibility of the government's commitment to such

103 World Bank, Worldwide Governance Indicators, op. cit.

104 D. Kaufmann et al., op. cit. 
policies', and regulatory quality, capturing 'perceptions of the ability of the government to formulate and implement sound policies and regulations that permit and promote private sector development ${ }^{305}$. In both this dimensions Poland scores higher than Latin American countries (with the exception of Chile).

Figure 6. WGI - government effectiveness and regulatory quality

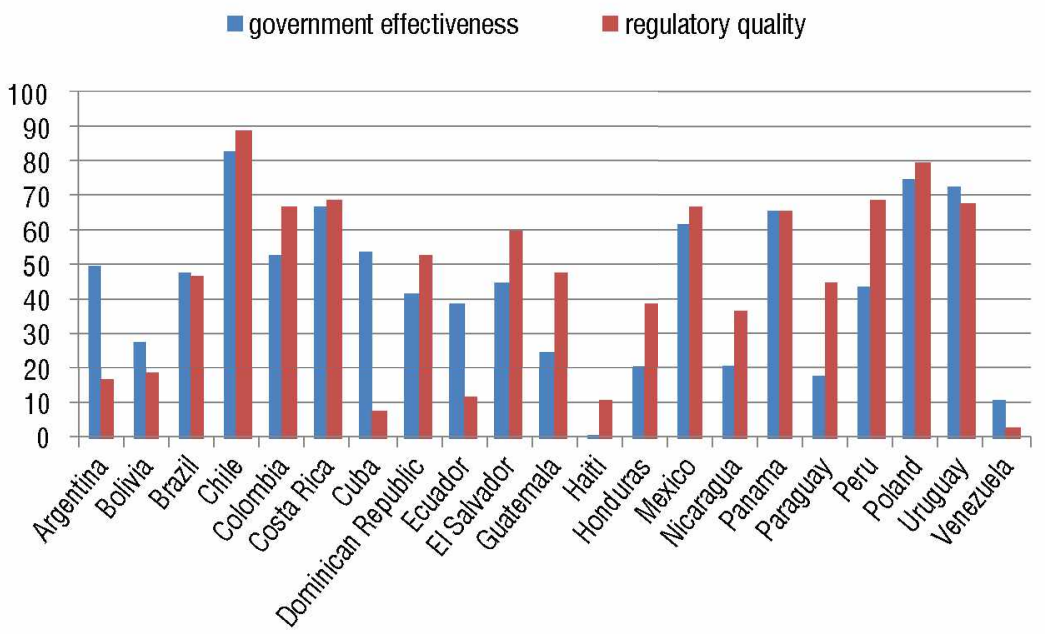

Source: own study based on World Bank. See World Bank, Worldwide Governance Indicators, op. cit.

Figure 7 presents last two governance indicators: rule of law, capturing the extent to which agents have confidence in and abide by the rules of society, and in particular the quality of contract enforcement, property rights, the police, and the courts, as well as the likelihood of crime and violence' and control of corruption, referring to the 'perceptions of the extent to which public power is exercised for private gain, including both petty and grand forms of corruption, as well as 'capture' of the state by elites and private interests ${ }^{106}$. In terms of the rule of law, Poland is outperformed only by Chile. On 'control of corruption' Poland scores higher than most of the Latin American countries, with the exception of Chile, Uruguay and Costa Rica.

The above analysis reveals that Latin America is extremely heterogeneous in terms of governance quality. On most dimensions, Chile, Costa Rica and Uruguay achieve the level comparable to Poland or higher, while other countries score considerably

105 Ibidem.

106 Ibidem. 
lower. In this sense, the administrative distance between Poland and, for example, Chile is much lower than between Chile and Venezuela, Cuba or Haiti.

Figure 7.WGI - government effectiveness and regulatory quality

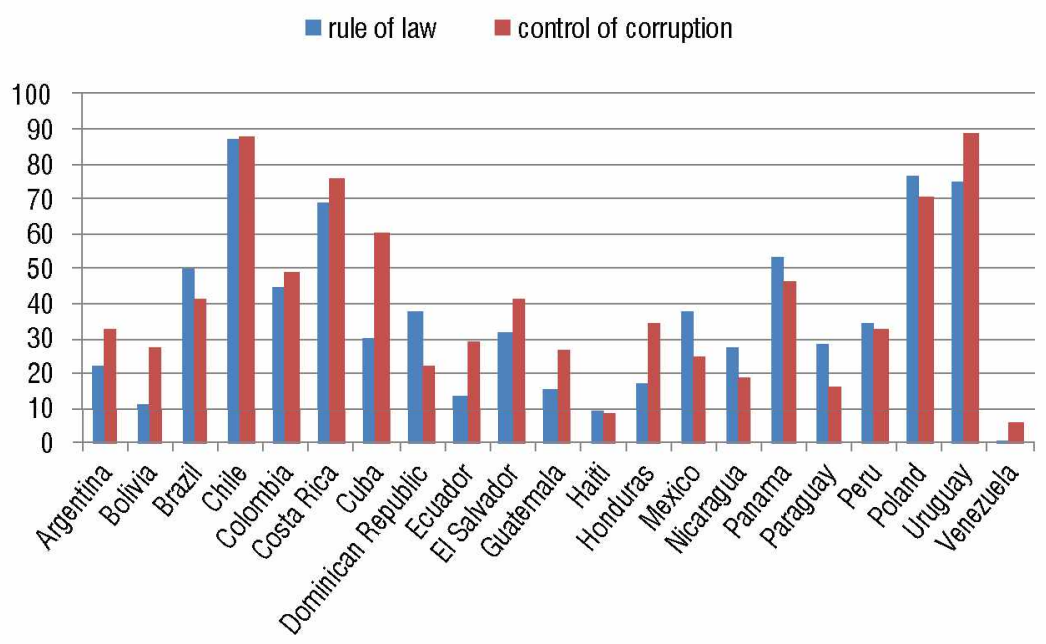

Source: own study based on World Bank. See World Bank, Worldwide Governance Indicators, op. cit.

Poland maintains diplomatic relations with all Latin American countries, with eight embassies (i.e. Argentina, Brazil, Chile, Colombia, Cuba, Mexico, Peru, Venezuela) and one Consulate General in Curitiba (Brazil). However, the intensity of country-level dialog between Poland and Latin America is very low, as the region occupies a rather marginal place in the Polish foreign policy ${ }^{107}$. The accession of Poland to the EU contributed to lowering the barriers to entry to some Latin American countries, with which the EU has trade agreements (Mexico - since 2000, Chile - since 2003, Colombia and Peru - since 2013) ${ }^{108}$.

\section{Geographic distance}

Geographic distance between Poland and Latin America is significant, with flight distance and travel time between Warsaw and respective capitals ranging from 8474 kilometres, i.e. 10 hours 29 minutes (for Dominican Republic) to 12982 kilometres, i.e. 15 hours 51 minutes (for Chile) (see Table 5). In terms of availability of transportation, there are no direct flights from Poland to Latin American countries.

${ }^{107}$ K. Brudzińska, M. Rostowska M., op. cit.

108 Ibidem. 
Therefore, the total travel time (including transfers) from Warsaw to Mexico City takes approximately 15 hours, to Brasilia - 19 hours and to Buenos Aires -21 hours.

Table 5. Geographic distance between Poland and Latin American countries

\begin{tabular}{|l|c|c|}
\hline \multicolumn{1}{|c|}{ Country } & Flight distance $(\mathrm{km})$ & travel time \\
\hline Argentina & 12322 & $15 \mathrm{~h} 4 \mathrm{~min}$ \\
\hline Bolivia & 11425 & $14 \mathrm{~h} \mathrm{0} \mathrm{min}$ \\
\hline Brazil & 10037 & $12 \mathrm{~h} 28 \mathrm{~min}$ \\
\hline Chile & 12982 & $15 \mathrm{~h} 51 \mathrm{~min}$ \\
\hline Colombia & 9957 & $12 \mathrm{~h} 15 \mathrm{~min}$ \\
\hline Costa Rica & 10158 & $12 \mathrm{~h} 29 \mathrm{~min}$ \\
\hline Cuba & 8732 & $10 \mathrm{~h} 47 \mathrm{~min}$ \\
\hline Dominican Republic & 8474 & $10 \mathrm{~h} 29 \mathrm{~min}$ \\
\hline Ecuador & 10685 & $13 \mathrm{~h} 7 \mathrm{~min}$ \\
\hline El Salvador & 10124 & $12 \mathrm{~h} 27 \mathrm{~min}$ \\
\hline
\end{tabular}

\begin{tabular}{|l|c|c|}
\hline \multicolumn{1}{|c|}{ Country } & Flight $(\mathrm{km})$ & travel time \\
\hline Guatemala & 10026 & $12 \mathrm{~h} 20 \mathrm{~min}$ \\
\hline Haiti & 8594 & $10 \mathrm{~h} 37 \mathrm{~min}$ \\
\hline Honduras & 9830 & $12 \mathrm{~h} 6 \mathrm{~min}$ \\
\hline Mexico & 10211 & $12 \mathrm{~h} \mathrm{33min}$ \\
\hline Nicaragua & 9974 & $12 \mathrm{~h} 16 \mathrm{~min}$ \\
\hline Panama & 10071 & $12 \mathrm{~h} 23 \mathrm{~min}$ \\
\hline Paraguay & 11470 & $14 \mathrm{~h} 3 \mathrm{~min}$ \\
\hline Peru & 11621 & $14 \mathrm{~h} 14 \mathrm{~min}$ \\
\hline Uruguay & 12217 & $14 \mathrm{~h} 56 \mathrm{~min}$ \\
\hline Venezuela & 8966 & $11 \mathrm{~h} 4 \mathrm{~min}$ \\
\hline
\end{tabular}

Source: own study based on http://flighttime-calculator.com/

\section{Economic distance}

In order to assess the economic distance between Poland and Latin American countries differences in the GDP per capita and the GINI index, indicating the level of disparities within a society are being analysed (see Figure 8).

Figure 8. GDP per capita (in US dollars in 2005 prices, 2015) and GINI Index

GINI Index G GDP per capita

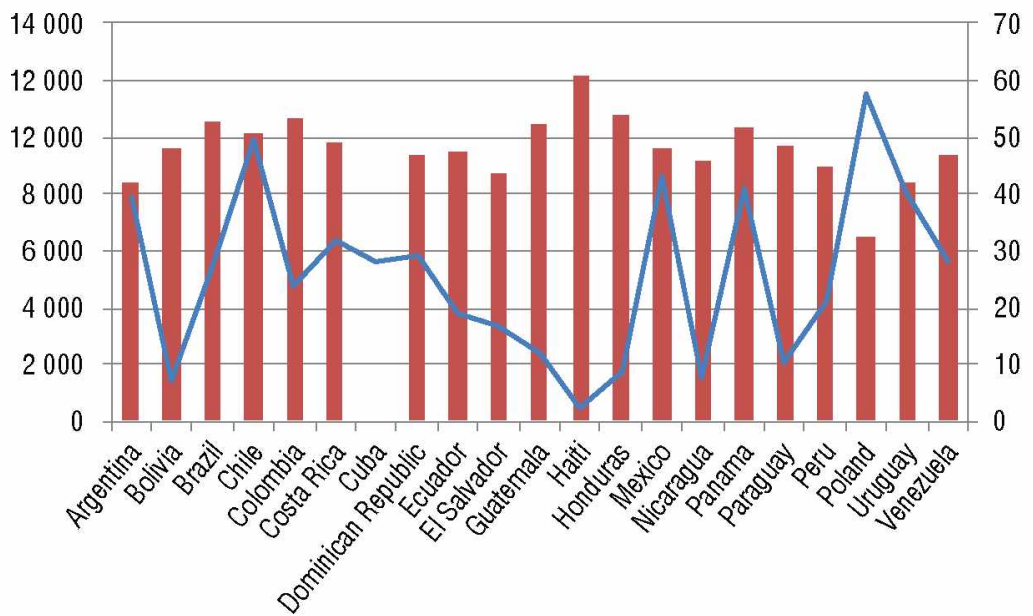

Source: own study based on UNCTAD (2016) and World Bank (2016). 
In terms of GDP per capita, Poland scores higher than all the Latin American countries. Similarly to governance quality, the level of economic development differs considerably across Latin American countries, with Chile, Mexico and Panama achieving the highest, and Haiti, Bolivia and Nicaragua - the lowest GDP per capita in the region. In all Latin American countries the GINI index is considerably higher than in Poland, achieving the highest values in Haiti, Colombia, Honduras, Brazil, Guatemala and Panama.

\section{Psychic distance}

The perception of distance, which is the actual driver of decisions in the internationalisation process, is highly subjective and individual-specific. It depends not only on objective 'psychic distance stimuli ${ }^{109}$, discussed within the CAGE framework, but also on the individual predispositions and experience. Therefore, it is unable to assess the psychic distance based on the macro-level, secondary data. In order to shed light on the 'perceptual' dimension of distance between Poland and Latin America, authors use the measures elaborated by Hakanson and Ambos ${ }^{110}$, based on a study performed on a sample of 1400 managers from 25 largest economies (including Poland, Argentina, Brazil and Mexico).

Due to the perceptual nature of the concept, psychic distance is not symmetric, i.e. the reciprocal distance perceived by managers from two countries (i.e. distance to and distance from) will differ (see Figure 9). Hakanson et al. ${ }^{111}$ reveal that the formation of psychic distance is driven by the psychological 'mere exposure effect', which states that the frequent exposure to a certain object increases the perceived attractiveness of this object ${ }^{112}$. More specifically, they find that exposure to a country through emigrants and import of cultural goods decreases the psychic distance towards this country. Moreover, inhabitants of small countries tend to perceive distance towards the rest of the world as smaller than inhabitants of large countries.

As evidenced by Figure 9, for Polish managers, the most proximate countries (in terms of psychic distance) are Germany, Italy, Austria and UK. The assessment of distance in country pairs (Poland-Germany, Poland-Italy, Poland-Austria, Poland-UK) is, however, highly asymmetric, with distance to Poland, assessed by the managers in the respective countries, being much higher than distance from Poland, assessed

${ }_{109}$ D. Dow, A. Karunaratna, op. cit.

${ }^{110}$ L. Hakanson, B. Ambos, op. cit.

111 L. Hakanson et al., The Psychology of Psychic Distance: Antecedents of Asymmetric Perceptions, "Journal of World Business" 2016, vol. 51, pp. 308-318.

112 R.B. Zajonc, The Attitudinal Effects of Mere Exposure, "Journal of Personality and Social Psychology" 1968, vol. $92(2 / 2)$, pp. 1-27. 
by the Polish managers. This asymmetry may be explained by the 'mere exposure effect $^{113}$, as Polish managers are typically much more exposed to the Western European countries (e.g. through import of products, including cultural goods, as well as incoming FDI) than the Western European managers to Poland.

\section{Figure 9. Psychic distance to and from Poland}

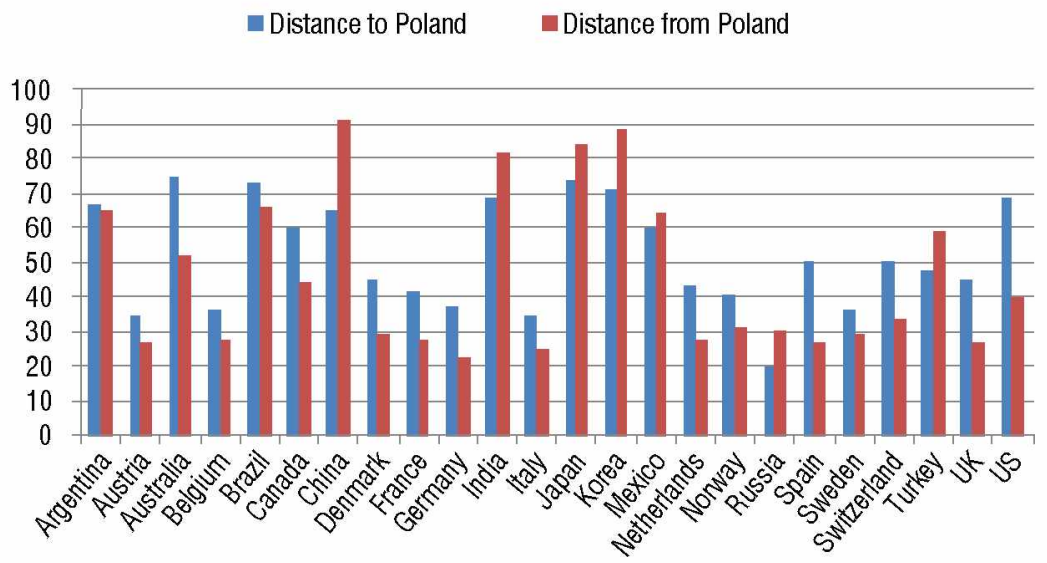

Source: own study based on Hakanson, Ambos. See L. Hakanson, B. Ambos, op. cit.

The perceived distance from Poland to Argentina, Brazil and Mexico is at a very similar, high level (with only four destinations - China, India, Japan and Korea scoring higher). Moreover, the asymmetries in country pairs (Poland-Argentina, Poland-Brazil, Poland-Mexico) are lower than for Western European economies, with distance from Poland to Mexico slightly higher than vice versa and distance from Poland to Argentina and from Poland to Brazil slightly lower than vice versa. This asymmetry may be explained by the effect of emigration ${ }^{114}$. Polish diaspora present in Argentina and Brazil may contribute to lowering the psychic distance from Poland to these countries, though this effect is rather limited, as the scores of psychic distance are high.

113 L. Hakanson et al., op. cit.

114 Ibidem. 


\section{Conclusion}

The objective of this paper was to evaluate the current state of the internationalisation of Polish firms in Latin America and to indicate the main distant-related barriers to internationalisation of Polish firms in Latin America.

It is concluded that the activity of Polish firms in Latin America is very limited. Both Polish exports and FDI are focused on the EU markets. Latin America is one of the least represented regions in the structure of Polish trade and foreign investment. Most of the largest exporters to Latin America are Polish subsidiaries of multinational corporations headquartered in Western Europe or US. Thus, the Polish trade with Latin America is, to a large extent, attributable to the activity of multinational corporations, which have located parts of their value chains in Poland.

Polish firms are very reluctant to enter Latin American markets through FDI. Those who did invest in Latin America are typically large, mature and geographically diversified. Even for these firms, however, FDIs in Latin America are challenging and often fail.

The limited activity of Polish firms in Latin America may be explained by the early stage of internationalisation of Polish economy. Before 1989, Polish firms were nearly non-existent in foreign markets. After 1989, the Polish economy has opened to the world, which resulted in a dramatic increase of export, import and inward FDI. However, outward FDI started only very recently and its value has been very modest, with Poland being still at the second stage of the Investment Development Path ${ }^{115}$. At the micro-level, the limited presence of Polish firms in Latin America may be explained by the fact that most of them are at an early stage of internationalisation lifecycle and they have not developed enough resources or experience to successfully venture to distant markets.

The Uppsala model of internationalisation predicts that firms start internationalisation in proximate markets and gradually enter more 'psychically' distant countries $^{116}$. Polish managers assess the distance between Poland and Latin American countries as very high ${ }^{117}$. This is due to a number of 'psychic distance stimuli', such as geographic distance, as well as cultural, institutional and economic differences. Our analysis, based on the CAGE framework, reveals a number of differences between

115 M. Gorynia, J. Nowak, R. Wolniak, Poland's Investment Development Path: In Search of a Synthesis, "International Journal of Economic Policy in Emerging Economies", 2009, vol. 2(2), pp. 153-174.

116 J. Johanson, J.-E. Vahlne, op. cit.

117 L. Hakanson, B. Ambos, op. cit. 
Poland and Latin America, on all these dimensions. Moreover, the findings indicate that Latin America is not a homogeneous region and both the market attractiveness and the distance from Poland differ across the countries.

The conducted study has two major limitations. First, given the early stage of research on internationalisation of Polish companies in regard to distant markets, as well as the novelty of the phenomenon itself, the study is exploratory in nature. Therefore, instead of formulating and testing research hypotheses, the reader is offered with a description of the activities of Polish firms in Latin America and distance-related barriers to internationalisation in connection to this region are being reviewed. Second, the obtained findings are based on secondary data. Thus, authors argue that future research into the phenomenon of internationalisation in reference to distant countries is needed. More specifically, future studies might use qualitative research techniques, that would enable to understand how different dimensions of distance affect the internationalisation choices and their outcomes. Moreover, it would be useful to shed more light on the mechanisms that contribute to bridging the distance (e.g. the significance of Polish diaspora in Latin America, the role of institutional support for internationalisation in regard to distant markets). Finally, quantitative studies are needed to draw conclusive findings on the firm-specific attributes through which companies overcome distant-related barriers to internationalisation. The measurement of distance in quantitative studies may be based on aggregate indices of psychic distance stimuli or the subjective measures of distance perceived by the decision-makers.

The practical implications of the performed work are as follows. It is concluded that the calls for Polish firms 'going global' (instead of 'going regional') should be treated with caution. Although some managers (and policymakers) '(...) seem to share unquestioned assumptions about the need to go global ${ }^{118}$, extant research indicates the performance-related advantages of region-focused expansion over distant markets internationalisation ${ }^{119}$. Taking into consideration the early stage of internationalisation of Polish economy, the limited international experience of Polish firms and a high psychic distance resulting from geographic, cultural, administrative and economic differences between Poland and Latin America, it is argued that the majority of Polish firms are unprepared to successfully venture to these markets.

${ }_{118}$ M. Alexander, H. Korine, When You Shouldn't Go Global, "Harvard Business Review" 2008, vol. 86, pp. $60-77$.

119 A.M. Rugman et al., op. cit. 


\section{References}

1. Alexander M., Korine H., When You Shouldn't Go Global, "Harvard Business Review" 2008, vol. 86, pp. 60-77.

2. Arendarski A., Polscy przedsiębiorcy w UE. 10 lat doświadczeń wobec wyzwań przyszłości, "Bezpieczeństwo Narodowe" 2014, vol. 4, pp. 125-137.

3. Barkema H., Bell J., Pennings J., Foreign Entry, Cultural Barriers and Learning, "Strategic Management Journal" 1996, vol. 17(2), pp. 151-166.

4. Bartlett C.A., Ghoshal S., Managing Across Borders: The Transnational Solution, Harvard Business School Press, Boston 1989.

5. BGK, Financial Support for Exporters. Government Programme, Warsaw 2015, https:// www.bgk.pl/files/public/Pliki/Przedsiebiorstwa/Government_Programme_Financial_Support_for_Exporters.pdf (15.10.2016).

6. Boeh K., Beamish P., Travel Time and the Liability of Distance in Foreign Direct Investment: Location Choice and Entry Mode, "Journal of International Business Studies" 2012, vol. 43(5), pp. 525-535.

7. Boski P., Kulturowe ramy zachowań spolecznych, Wydawnictwo Naukowe PWN, Warsaw 2009.

8. Boyacigiller N., The Role of Expatriates in the Management of Interdependence, Complexity and Risk in Multinational Corporations, "Journal of International Business Studies" 1990, vol. 21(3), pp. 357-381.

9. Brouthers K., Brouthers L., Explaining the National Cultural Distance Paradox, "Journal of International Business Studies" 2001, vol. 32(1), pp. 177-189.

10. Brudzińska K., Visão Geral das Relações Polônia-Brasil, "A União Europeia Alargada em tempos de novos desafios", Fundação Konrad Adenauer Stiftung, Rio de Janeiro 2014, pp. 163-174.

11. Brudzińska K., Rostowska M., Latin America and the Caribbean Countries and Central-Eastern Europe - Potential for Economic Cooperation: Polish Case Study, EU-LAC Foundation, Polish Institute of International Affairs, Warsaw 2014.

12. Brudzińska K., Znojek B., Poland and Brazil: Narrowing the Distance, Exploring Mutual Potential, Policy Paper no. 46, Polish Institute of International Affairs, Warsaw 2012.

13. Carr D.L., Markussen J.R., Maskus K.E., Estimating the Knowledge-Capital Model of the Multinational Enterprise, "American Economic Review" 2001, vol.91(3), pp. 693-708.

14. Castaño N., de Luque M., Wersing T., Ogliastri E., Fuchs R., Shemueli R., Robles J., El Jefe: Differences in Expected Leadership Behaviors across Latin America, "Journal of World Business" 2015, vol. 50(3), pp. 584-597. 
15. Central Statistical Office, Działalność podmiotów posiadajacych jednostki zagraniczne w latach 2008-2014, Warsaw 2016.

16. Central Statistical Office, Yearbook of Foreign Trade Statistics of Poland 2015, Warsaw 2016.

17. CEPAL, Anuario Estadístico de América Latina y el Caribe, Santiago de Chile 2014.

18. Cieślik A., International Trade under Monopolistic Competition: Evidence from Polish Bilateral Trade Data, European Trade Study Group, Warsaw 2006, http://www.etsg. org/ETSG2006/papers/cieslik.pdf (25.10.2016).

19. Ciszewska-Mlinarič M., Trąpczyński P., The Psychic Distance Concept: A Review of 25 Years of Research (1990-2015), "Journal of Management and Business Administration. Central Europe” 2016, vol. 24(2), pp. 2-31.

20. Ciszewska-Mlinarič M., Wąsowska A., Znaczenie dystansu w procesie internacjonalizacji przedsiębiorstw, "Management and Business Administration. Central Europe" 2012, vol. 6(119), pp. 3-22.

21. Davis S.M., United States versus Latin America: Business and Culture, "Harvard Business Review" 1996, vol. 47(6), pp. 15-24.

22. Dow D., Karunaratna A., Developing a Multidimensional Instrument to Measure Psychic Distance Stimuli, “Journal of International Business Studies” 2006, vol. 37(5), pp. 578-602.

23. Edwards R.W., Buckley P.J., Choice of Location and Mode: The Case of Australian Investors in the U.K., "International Business Review" 1998, vol. 7(5), pp. 503-520.

24. EF English Proficiency Index, http://www.ef.pl/epi/ (3.11.2016).

25. El Economista, Empresas polacas salen a la conquista del mercado de la belleza en Chile, 15.10.2015.

26. Erramilli M.K., Nationality and Subsidiary Ownership Patterns in Multinational Corporations, "Journal of International Business" 1996, vol. 27(2), pp. 225-248.

27. Evans J., Mavondo F., Psychic Distance and Organizational Performance: An Empirical Examination of International Retailing Operations, "Journal of International Business Studies" 2002, vol. 33(3), pp. 515-532.

28. Flightime Calculator, http://flighttime-calculator.com/ (1.11.2016).

29. Frankel J., Rose A., An Estimate of the Effect of Common Currencies on Trade and Income, "Quarterly Journal of Economics" 2002, vol. 117(2), pp. 437-466.

30. Ghemawat P., Distance Still Matters: The Hard Reality of Global Expansion, "Harvard Business Review” 2001, vol. 79(8), pp. 137-147.

31. Góralczyk B., Stawiajmy na wschodzace rynki, "Obserwator Finansowy", 27.04.2015. 
32. Gorynia M., Nowak J., Wolniak R., Fostering Competitiveness of Polish Firms: Some Musings on Economic Policy and Spatial Expansion, in: International Management Development Research Yearbook, eds. E. Kaynak, T. Harcar, IMDA, Pennsylvania 2005.

33. Gorynia M., Nowak J., Wolniak R., Poland's Investment Development Path: In Search of a Synthesis, "International Journal of Economic Policy in Emerging Economies" 2009, vol. 2(2), pp. 153-174.

34. Hakanson L., Ambos B., Schuster A., Leicht-Deobald U., The Psychology of Psychic Distance: Antecedents of Asymmetric Perceptions, "Journal of World Business" 2016, vol. 51 , pp. $308-318$.

35. Hakanson L., Ambos B., The Antecedents of Psychic Distance, "Journal of International Management" 2010, vol. 16(3), pp. 195-210.

36. Hofstede G., Culture’s Consequences: Comparing Values, Behaviors, Institutions, and Organizations Across Nations, Sage, London 2001.

37. House R.J., Hanges P.J., Javidan M., Dorfman P.W., Gupta V., Culture, Leadership, and Organizations, The Globe Study of 62 Societies, Sage, Thousand Oaks 2004.

38. Hummels D., Transportation Costs and International Trade in the Second Era of Globalization, "Journal of Economic Perspectives" 2007, vol. 21(3), pp. 131-154.

39. Hymer S.H., The International Operations of National Firms: A Study of Direct Foreign Investment, MIT Press, Cambridge 1976.

40. Instituto Cervantes, El español: una lengua viva. Informe 2013, http://cvc.cervantes. es/lengua/anuario/anuario_13/i_cervantes/p01.htm (15.10.2016).

41. Jarosiński M., Procesy i modele internacjonalizacji polskich przedsiębiorstw, SGH, Warsaw 2013.

42. Johanson J., Vahlne J.-E., The Internationalisation Process of the Firm - A Model of Knowledge Development and Increasing Foreign Market Commitments, "Journal of International Business Studies" 1977, vol. 8(1), pp. 23-32.

43. Kaufmann D., Kraay A., Mastruzzi M., The Worldwide Governance Indicators: Methodology and Analytical Issues, The World Bank, Policy Research Working Paper no. 5430, 2010.

44. Khanna T., Palepu K., Winning in Emerging Markets, Harvard Business Press, Boston 2010.

45. Kogut B., Singh H., The Effect of National Culture on the Choice of Entry Mode, "Journal of International Business Studies" 1988, vol. 19(3), pp. 411-432.

46. Kostova T., Zaheer S., Organizational Legitimacy Under Conditions of Complexity: The Case of the Multinational Enterprise, "Academy of Management Review" 1999, vol. 24(1), pp. 64-81.

47. Lara G., Polonesa Synthos vai investir até $R \$ 640$ milhões no RS, “Estadão”, 26.01.2015. 
48. Leonidou L.C., Empirical Research on Export Barriers: Review, Assessment, and Synthesis, "Journal of International Management" 1995, vol. 3(1), pp. 29-43.

49. Maflow, Ya hemos llegado a México, http://www.maflow.es/ya-hemos-legado-mexico/ (15.10.2016).

50. Makino S., Lau C.-M., Yeh R.-S., Asset-Exploitation Versus Asset-Seeking: Implications for Location Choice of Foreign Direct Investment from Newly Industrialized Economies, "Journal of International Business Studies" 2002, vol. 33(3), pp. 403-421.

51. Ministerstwo Rozwoju, Notatka informacyjna o polsko-meksykańskich stosunkach gospodarczych, 20.09.2016, https://www.mr.gov.pl/media/26597/Meksyk_20_09_2016. pdf (2.11.2016).

52. Ministerstwo Rozwoju, Plan działalności Ministra Rozwoju na rok 2016, http://mr.bip. gov.pl/plan-dzialalnosci-ministerstwa/plan-dzialalnosci-na-2016-r.html (4.11.2016).

53. Ministerstwo Rozwoju, Polskie bezpośrednie inwestycje zagraniczne w 2014 roku, https://www.mr.gov.pl/media/18110/Polskie_inwestycje_bezposrednie_2014.pdf (3.11.2016).

54. Ministerstwo Rozwoju, Programy promocji na rynkach perspektywicznych, https:// www.mr.gov.pl/strony/zadania/wspolpraca-miedzynarodowa/wspolpraca-gospodarcza/promocja-eksportu/\#Programy\%20promocji\%20na\%20rynkach\%20perspektywicznych (4.11.2016).

55. Moon T.W., Park S. II., The Effect of Cultural Distance on International Marketing Strategy: A Comparison of Cultural Distance and Managerial Perception Measures, "Journal of Global Marketing" 2011, vol. 24(1), pp. 18-40.

56. Morosini P., Shane S., Singh H., National Cultural Distance and Cross-Border Acquisition Performance, "Journal of International Business Studies" 1998, vol. 29(1), pp. 137-158.

57. National Bank of Poland, Polskie inwestycje bezpośrednie za granica, http://www.nbp. pl/home.aspx?f=/publikacje/pib/pib.html (28.10.2016).

58. North D.C., Institutions, Institutional Change and Economic Performance, Cambridge University Press, Cambridge 1990.

59. Nowiński W., Nowara W., Stopień i uwarunkowania internacjonalizacji polskich malych iśrednich przedsiębiorstw, "Gospodarka Narodowa” 2011, vol. 3, pp. 29-45.

60. Padmanabhan P., Cho K.R., Ownership Strategy for a Foreign Affiliate: An Empirical Investigation of Japanese Firms, "Management International Review" 1996, vol. 36(1), pp. 45-65.

61. Pazarán P., México y Polonia, socios estratégicos, "Fortuna”, 18.12.2012.

62. Polish Institute of International Affairs, Promocja polskiej gospodarki za granica, Warsaw 2014, https://www.pism.pl/files/?id_plik=17520 (15.10.2016). 
63. Protocolo, Polonia busca incrementar lazos con México, "Protocolo", 1.11.2002.

64. Robertson K.R., Wood V., The Relative Importance of Type of Information in the Foreign Market Selection Process, "International Business Review" 2001, vol. 10(3), pp. 363-379.

65. Romero E.J., Latin American Leadership: el Patrón \& el Lider Moderno, "Cross Cultural Management: An International Journal” 2004, vol. 11, pp. 25-37.

66. Ronen S., Shenkar O., Clustering Countries on Attitudinal Dimensions: A Review and Synthesis, "Academy of Management Review" 1985, vol. 10, pp. 435-454.

67. Rugman A.M., Bain C., Multinational Enterprises Are Regional, Not Global, "Multinational Business Review" 2003, vol. 11(1), pp. 3-12.

68. Rugman A.M., Yip G.S., Jayaratne S.A., Note on Return on Foreign Assets and Foreign Presence for UK Multinationals, "British Journal of Management" 2008, vol. 19(2), pp. 162-170.

69. Schwartz S.H., Value Orientations: Measurement, Antecedents and Consequences Across Nations, in: Measuring Attitudes Cross-National - Lessons from the European Social Survey, eds. R. Jowell, C. Roberts, R. Fitzgerald, G. Eva, Sage, London 2006.

70. Scott W.R., Institutions and Organization. Ideas, Interests, and Identities, Sage, Los Angeles-London-New Delhi-Singapore-Washington 2014.

71. Shenkar O., Cultural Distance Revisited: Towards a More Rigorous Conceptualization and Measurement of Cultural Differences, "Journal of International Business Studies" 2001, vol. 32(3), pp. 519-535.

72. Śliwiński R., Zróżnicowanie przestrzenne i strategie internacjonalizacji polskich przedsiębiorstw, "Przegląd Organizacji" 2012, vol. 4, pp. 15-19.

73. Spychała M., Kształcenie nauczycieli języka hiszpańskiego w Polsce i na świecie: wyzwania i potrzeby edukacyjne, in: Nauczanie języków obcych na potrzeby rynku pracy, eds. M. Sowa, M. Mocarz-Kleindienst, U. Czyżewska, Wydawnictwo KUL, Lublin 2015.

74. Stowarzyszenie 'Wspólnota Polska', Polonia w liczbach, http://swp4.wspolnotapolska. org.pl/polonia_w_liczbach.html (15.10.2016).

75. Sudak I., KGHM zrejteruje z Chile? Rekordowa polska inwestycja może zakończý́ się klapa, "Gazeta Wyborcza”, 25.10.2016.

76. Tinbergen J., Shaping the World Economy: Suggestions for an International Economic Policy, New York 1962.

77. Tsang E., Yip P., Economic Distance and the Survival of Foreign Direct Investment, "Academy of Management Journal" 2007, vol. 50(5), pp. 1156-1168.

78. TVN24bis, Meksyk 'brama' dla dużej polskiej firmy. Boryszew wziąt kredyt, by rozwijać się poza Polska, http://tvn24bis.pl/z-kraju,74/boryszew-wzial-10-mln-euro-kredytu-w-bgk,551578.html (15.10.2016). 
79. UNCTAD, Statistics, United Nations Conference on Trade and Development, http:// unctadstat.unctad.org/EN/Index.html (28.10.2016).

80. United Nations, UN Global Migrant Origin Database, https://esa.un.org/unmigration/index.aspx (15.10.2016).

81. Vernon R., International Investment and International Trade in the Product Cycle, "Quarterly Journal of Economics" 1966, vol. 80(2), pp. 190-207.

82. Wach K., Europeizacja malych i średnich przedsiębiorstw: rozwój przez umiędzynarodowienie, Wydawnictwo Naukowe PWN, Warsaw 2012.

83. World Bank, World Integrated Trade Solution, http://data.worldbank.org/data-catalog/ wits (28.10.2016).

84. World Bank, Worldwide Governance Indicators, http://info.worldbank.org/governance/ wgi/index.aspx\#home (2.11.2016).

85. World Christian Database, quoted by: BBC, How Many Roman Catholics Are They in the World?, http://www.bbc.com/news/world-21443313 (3.11.2016).

86. Xu D., The Effect of Institutional Distance on Multinational Enterprise Strategy, Unpublished doctoral thesis, York University, Toronto 2001.

87. Zajonc R.B., The Attitudinal Effects of Mere Exposure, "Journal of Personality and Social Psychology" 1968, vol. 92 (2/2), pp. 1-27.

88. Znojek B., Emerging Latin America: A Case for Increasing Poland's Interest in the Region, PISM Strategic File no. 25, Polish Institute of International Affairs, Warsaw 2012. 